\title{
Blaualgenliteratur aus den Jahren 1967 und 1968 mit Ergänzungen aus den Jahren 1960 bis 1966
}

Die beiden Zusammenstellungen über «Blaualgenliteratur aus den Jahren 1960 1963» bzw. «1960-1966», die nach Beschluss der "Internationalen Arbeitsgemeinschaft für Cyanophytenforschung (IAC) " in der Schweizerischen Zeitschrift für Hydrologie in den Jahren 1964 und 1967 erschienen, sind gut aufgenommen worden. Wir finden es daher sinnvoll, diese begonnene Literatursammlung fortzuführen und die dritte Folge einer solchen Zusammenstellung - wiederum Ergänzung und Fortsetzung zugleich - an dieser Stelle zu veröffentlichen. Wir sind überzeugt, dass die zahlreichen Arbeiten verschiedenster Blaualgenrichtungen sowohl Algologen als auch Pflanzenphysiologen, Ökologen, Systematikern und Biochemikern nützliche Hinweise geben.

Wiederum haben uns eine Reihe von Spezialisten aus mehreren Ländern mit ihren Mitteilungen wertvolle Hilfe geleistet, so dass nachfolgende Listen zusammengestellt werden konnten: 1. Ergänzungen zur Blaualgenliteratur aus den Jahren 1960-1963, 2. Ergänzungen zur Blaualgenliteratur aus den Jahren 1964-1966 und 3. Blaualgenliteratur aus den Jahren 1967 und 1968.

Für die besonders zahlreichen Beiträge möchten wir an erster Stelle Dr. B. A. WhitTon (England) und Dr. J. KOMÁREK (Tschechoslowakei) unseren herzlichen Dank aussprechen. Ferner danken wir Dr. Asta Almestrand (Schweden), Prof. Dr. V. J. Chapman (New Zealand), Dr. S. Golubić (USA), Dr. J. Umesaki (Japan) und Dr. I. Wojciechowski (Polen) herzlich für ihre Bemühungen.

Die Sachgebiete wurden wiederum anhand von folgenden Stichwörtern gekennzeichnet:

$$
\begin{aligned}
& \mathrm{B}=\text { Biochemie } \\
& \mathrm{C}=\text { Cytologie, Varia } \\
& \mathrm{CU}=\text { Cytologie, Feinstruktur } \\
& \mathrm{K}=\text { Kulturmethoden } \\
& \mathrm{M}=\text { Morphologie } \\
& \mathrm{O}=\text { Ókologie }
\end{aligned}
$$

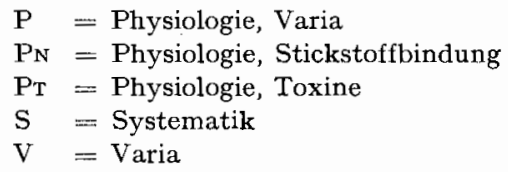

Marianne Pavoni 


\section{Ergänzungen zur Blaualgenliteratur aus den Jahren 1960-1963}

Amesz, J., Duysens, L. N. M., Action Spectrum, Kinetics and Quantum Requirement of Phosphopyridine Nucleotide Reduction and Cytochrome Oxidation in the Blue-Green Alga Anacystis nidulans, Biochim. Biophys. Acta 64, 261-278 (1962). P.

Amesz, J., Duysens, L. N. M., Brandt, D. C., Methods for Measuring and Correcting the Absorption Spectrum of Scattering Suspensions, J. Theor. Biol. 1, $59-74$ (1961). P (inkl. Anacystis).

Arnon, D. I., Losada, M., Whatley, F. R., Tsujimoto, H. Y., Hall, D. O., Horton, A. A., Photosynthetic Phosphorylation and Molecular Oxygen, Proc. Nat. Acad. Sci. 47, 1314-1334 (1961). B.

Azız, K. M. S., IsLam, N., A New Species of Fritschiella Iyengar from East Pakistan, Trans. Amer. Micr. Soc. 87, 185-189 (1962). S.

BaAlen, C. van, Marler, J. E., Characteristics of Marine Blue-Green Algae with Uric Acid as Nitrogen Source, J. gen. Microbiol. 32, 457-463 (1963). P.

Barghoorn, E. S., Tyler, S. A., Fossil Organisms from Pre-Cambrian Sediments, Ann. N. Y. Acad. Sci. 708, 451-452 (1963). V.

Bentley, J. A., Some Investigations on Interconvertible Naturally Occurving Auxins, aus: Plant Growth Regulation, Iowa State University, Ames. (1961). P (inlkl. Oscillatoria spp.).

Bergeron, J. A., Smillie, R. M., Some Aspects of the Fine Structure of the Blue-Green Alga, Anacystis nidulans, Plant Physiol. 36 (suppl.), xlviii-xlix (1961). Cu.

Bernard, F., Lecal, J., Plancton unicellulaive vécolté dans l'Océan Indien par le Chavcot (7950) et le Norsel (1955-7956), Bull. Inst. Océanogr. Monaco 1766, 1-59 (1960). O.

Berns, D. S., Crespi, H. L., Katz, J. J., Isolation, Amino-Acid Composition and Some PhysicoChemical Properties of the Protein Deuterio-Phycocyanin, J. Amer. chem. Soc. 85, 8 (1963). B.

Biswas, B. B., Studies on the Nucleoproteins of Nostoc muscorum, Trans. Bose Res. Inst. 24, 25-30 (1961). B.

Burkholder, P. R., Burkholder, L. M., Almodóvar, L. R., Antibiotic Activity of Some Marine Algae of Puerto Rico, Botanica Marina 2, 149-155 (1960). P.

Calvin, M., Quantum Conversion in Photosynthesis, J. Theor. Biol. 1, 258-287 (1961). P.

Cameron, R. E., Species of Nostoc Vaucher Occurring in the Sonoran Desert in Avizona, Trans. Amer. Micr. Soc. 81, 379-384 (1962). S.

Cameron, R. E., Morphology of Representative Blue-Green Algae, Ann. N. Y. Acad. Sci. 108, $412-420$ (1963). M.

ChIANg, Y. M., Marine Algae of Northern Taiwan (Cyanophyta, Chlovophyta, Phaeophyta), Taiwania $7,51-75(1960)$. S

Cocke, E. C., The Myxophyceae of North Carolina, Am. J. Bot. 50, 629 (1963). S.

Curby, W. A., McLeod, G. C., Bobblis, F. J., The Effect of Low kV P X-Rays on Photosynthetic Oxygen Evolution in the Blue-Gveen Alga Phormidium persicinum, aus: 7 th Annual Meeting of the Health Physics Society, 1962, Health Phys. 8, 459-460, (1962). P.

Daboll, H. F., Crespi, H. J.., Katz, J. J., Mass Cultivation of Algae in Pure Heavy Water, Biotech. Bioeng. 4, 281-297 (1962). K.

DE Halperin, D. R., Cianoficeas marinas de Puevto Deseado (Argentina). I. Dermocarpa solitaria Collins et Hervey, Darwiniana 12, 568-572 (1963). S.

Dillon, L. S., Comparative Cytology and the Evolution of Life, Evolution 16, $102-117$ (1962). C.

Dyer, D. L., GAFFord, R. D., The Use of Synechococcus lividus in Photosynthetic Gas Exchangers, Developments Industr. Microbiol. 3, 87-97 (1961). P.

Dyer, D. L., Richardson, D. E., Materials of Construction in Algal Culture, Appl. Microbiol. 10, 129-131 (1962). K.

Evans, J. H., Some New Records and Forms of Algae in Central East Africa, Hydrobiologia 20 , 59-86 (1962). S.

Fitzgerald, G. P., Faust, S. L., Factors Affecting the Toxicity of Copper to Algae and Fish, Am. J. Bot. 50, 629 (1963). P.

Fitzgerald, G. P., Faust, S. L., Factors Affecting the Algicidal and Algistatic Properties of Copper, Appl. Microbiol. 11, 345-351 (1963). P. 
FogG, G. E., Extracelluiar Products, aus: Ed. R. A. Lewin, Physiology and Biochemistry of Algae. pp. $475-489$ (1962). P, O.

Forest, H. S., Analysis of the Soil Algal Community, Trans. Am. Microscop. Soc. 81, 189-198 (1962). O.

FredrTCK, J. F., 3-amino-1,2,4-triazole Interference with Biosynthesis of Phosphorylases in Oscillatoria, Physiol. Plant. 16,822-827 (1963). B.

Fredrick, J. F., An Algal $\alpha$-glucan Phosphorylase which Requires Adenosine-5-phosphate as Coenzyme (Oscillatoria princeps), Phytochem. 2, 413-415 (1963). B.

FukUdA, I., Studies on Hill-Reaction in a Thermophilic Bhe-Green Alga, Cyanidium caldarium Geitler, Bot. Mag. Tokyo 75, 349-355 (1962). B.

Gaukmman, Z. S., Ryabov, F. P., The Interrelationships between the Blue-Green Algae and Bacterioflova of the Middle Dnepr and the Dnepr Reservoir, aus: Vysshaya Shkola pp. 33-35 (1962), russisch. $\mathrm{O}$.

Goedheer, J. C., An Attempted Concept of Photosynthesis Based on Luminescence Experiments, Colloques Internat. Ctr. Natl. Rech. Sci. 119, 147-159 (1963). P.

Govindjee, Observations on $P 750$ A from Anacystis nidulans, Naturwiss. 50, 720-721 (1963). P.

GovindJEe, Emerson Enhancement Effect and Two Light Reactions in Photosynthesis, aus: Photosynthesis Mechanisms in Green Plants, pp. 318-334, Publication No. 1145, National Academy of Sciences - National Research Council (1963). P.

Govindjee, Rabinowitch, E., Studies on the Second Emerson Effect in the Hill Reaction in Algal Cells, Biophys. J. 1, 371-388 (1961). P.

GRILLT, M., Osservazioni sulle infrastrutture di Anabaena cycadinae e delle cellule dei tubercoli radicali di Cycas revoluta, G. Bot. Ital. 70, 460-466 (1963). Cv.

Gusev, M. V., The Influence of Dissolved Oxygen on the Development of Blue-Green Algae, Dokl. Akad. Nauk S.S.S.R. 747, 947-950 (1962), russisch. P.

Gusev, M. V., The Study of the Status of Morphologically Differentiated Cells in Developing Cultures of Blue-Green Algae by Means of Triphenyl-tetrazolium Chloride, Byull. Moskov. Obshch. Isp. Prir. [n.s., Biol.] 67, 151-152 (1962), russisch. P.

Hoch, G., Owens, O. H., KoK, B., Photosynthesis and Respiration, Arch. Biochem. Biophys. 107, 171-180 (1963). P.

Hoch, G., Owens, O. H., Kок, B., Oxygen Metabolism in Anacystis nidulans, Colloques Internat. Ctr. Natl, Rech. Sci. 179, 262-272 (1963). P.

Holm-Hansen, O., Effect of Varying Residual Moisture Content on the Viability of Lyophilized Algae, Nature 198, 1014-1015 (1963). P.

Holm-HANSEN, O., Viability of Biwe-Green and Green Algae after Freezing, Physiol. Plant. 16, $530-540$ (1963). P.

Holm-Hansen, O., Brown, G. W., Jr., Ornithine Cycle Enzymes in the Blue-Green Alga Nostoc muscorum, Plant Cell Physiol. 4, 299-306 (1963). B.

Holton, R. W., Mrers, J., Cytochromes of a Blwe-Green Alga: Extraction of a c-Type with a Strongly Negative Redox Potential, Science 142, 234-235 (1963). B.

Hudecer, M., Duskova, D., Water Blooms in Several Reservoirs and Ponds in East Bohemia, Sb. Vysoke Sk. Chem. - Technol. Praze. Technol. Vody 7, 328-344 (1963). O.

Imazu, T., Hirose, H., Taxonomical and Ecological Studies of Algae Growing on Salt Farms at Oshio, Hyogo Prefecture, and its Vicinity, Hyogo Biol. 4, 73-77 (1961). O, S (inkl. Cyanophyceae).

Ishida, M. R., A Cytochemical Study of Nucleic Acids in Plant Cells. V. Nucleic Acids of Feulgen Negative Plants, Cytologia 26, 359-371 (1961). C (inkl. Oscillatoria).

Jones, W. E., A Key to the Genera of the British Seareeds, Field Studies 1 (4), 1-32 (1962). S.

Kamat, N. D., The Structure and Life-History of Fortiea bossei (FRémy) Desikachary v. indica v. nov., J. Biol. Sci. 5, 34-37 (1962). M.

Kato, K., Kato, T., A List of the Marine Algae from the Coast Akita Prefecture and Southern Part of Aomori Prefecture, Bull. Jap. Soc. Phycol. 11,62-70 (1963). O, S (inkl. Cyanophyceae).

Kempner, E. E., Upper Temperature Limit of Life, Science 142, 1318-1319 (1963). P.

Krndel, P., GrbBs, M., Distribution of Carbon-14 in Polysaccharide after Photosynthesis in Carbon Dioxide Labelled with Carbon-14 by Anacystis nidulans, Nature 200, 260-261 (1963). B. 
Kiyohara, T., Fujita, Y., Hattori, A., Watanabe, A., Effect of Light on Glucose Assimilation in Tolypothrix tenuis, J. gen. appl. Microbiol. 8, 165-168 (1962). P.

Lavorel, J., Monior, C., Action de la température sur les propriétés spectroscopiques de la phycocyanine, J. Chim. Phys. 59 (1962). B.

Lawson, G. W., A Preliminary Check-List of Ghanaian Fresh-and Brackish-Water Algae, J. West African Sci. Ass. 6, 122-136 (1960). S.

Lefèvre, M., LAPorte, G., Flandre, O., Sur la sécrétion par certaines Cyanophycées de substances stimulant la multiplication cellulaire, C. R. Acad. Sci. 256, 254-256 (1963). P.

Maruyama, K., Cyanophyceae from Lake Tairo and Sinmiyo (Myakei Islands), Reports of Students of Yokohama Municipal Univ. 8, 173-194 (1961). O, S.

Maruyama, K., Algal Communities at the Shore of Lake Sinmiyo, Reports of Students of Yokohama Municipal Univ. 8, 195-197 (1961). O.

McDaniel, H. R., Middlerook, J. B., Bowman, R. O., Isolation of Pure Cultures of Algae from Contaminated Cultures, Appl. Microbiol. 10, 223 (1962). P (inkl. Anacystis).

McLeod, G. C., Action Spectra of Light Saturated Photosynthesis, Plant Physiol. 36, 114-117 (1961). P (inkl. Phormidium).

Mehta, S. C., Das, S. C., Venkataraman, G. S., Chandra, R,, The Structure of the Sheath in Lyngbya majuscula Harvey ex Gomont, Curr. Sci. 32, $402-403$ (1963). C.

MENzEL, D. W., Inhibition of Photosynthesis by Trichodesmium in the Sargasso Sea, A. E. C. Rep. Contrib. AT(30-1)2646, Bermuda Biological Station, 6 pp. (1962). P.

Motoda, S., Marumo, R., Plankton of the Kuroshio Water (Proceedings of Symposium on the Kuroshio, October 29, 1963) p. 40-61 (1963). O (inkl. Cyanophyceae).

Moyse, A., Guyon, D., L'action de la température sur les propriétés de la phycocyanine el de la chlorophylle d'une Cyanophycée in vivo, Colloque Int. Photosynthèse, C. N. R. S., Gif-sur-Yvette, 1962, 119, 407-421 (1963). P.

Murray, R. G. E., Fine Structure and Tanonomy of Bacteria, aus: Microbial Classification, 12th Symp. Soc. Gen. Microbiol,, pp. 119-144 (1962). Cu (inkl. Cyanophyta).

Noble, A., A Note on the Occurvence of the Blue-Green Alga Aphanocapsa littoralis Hansg. var. macrococca HANsG. causing Colourations of the Sand and its Relation with the Tides, J. mar. biol. Ass. India 3, 262 (1961). O.

NoDA, M., On the Marine Flora of Sado Siraits in the Japan Sea, Bull. Jap. Soc. Phycol. 11, 109 114 (1963). O, S (inkl. Cyanophyceae).

O Carra, P., O heocha, C., Methionine, the N-Terminal Amino-acid of Phycoerythrins, Nature 195, 173-174 (1962). B.

Ó нЕосна, C., Spectral Properties of the Phycobilins. I. Phycocyanobilin, Biochemistry 2, 375-382 (1963). B.

O нEocha, C., Lambe, R. F., The Prosthetic Group of c-Phycocyanin, Arch. Biochem. Biophys. 93, 458-460 (1961). B.

OliveIRA, L. P. H. DE, Ruptura eletrolitica do regime hidrobiologico diminuindo saprobidade $e$ planctontes, Me. Inst. Oswaldo Cruz 60, 149-153 (1962). O.

Pandey, D. C., Mitra, A. K., On a New Species of Anabaenopsis, Annual Number 1960, National Academy of Sciences, India p. 66 (1961). S.

Parsons, T. R., On the Pigment Decomposition of Eleven Species of Marine Phytoplankters, J. Fish. Res. Board Canada 78, 1017-1025 (1961). B (inkl. Agmenellum).

Peary, J. A., Castenholz, R. W., Ecology and Physiology of Thermophilic Blue-Green Algae, Am. J. Bot. 50, 631 (1963). P.

Prasad, B. N., Glaucocystis nostochinearum (Itzigs.) Rabenhorst in India, Bull. Bot. Soc., University of Saugar 13, 44 45 (1961). S.

Prasad, B. N., On Some Cyanophyceae from India, J. Indian Bot. Soc. 41, 322-325 (1962). S.

RaJu, N. S., Parthasarathiella prolifica gen. et sp. nov. member of the Stigonemataceae, Trans. Amer. Micr. Soc. 81, 90-93 (1962). S.

Relwani, L. L., Subrahmanyan, S., Role of Blue-Green Algae, Chemical Nutrients and Partial Soil Stevilization on Paddy Yield, Curr. Sci. 32, 441-443 (1963). O.

Round, F. E., Some Algae from the Ennedi Mountains of Fvench Equatorial Africa, J. Roy. Micr. Soc. 80, 71-82 (1961). S. 
SaIto, Y., Notes on Some Marine Algae from Nou, in Echigo and Vicinity (4), Bull. Jap. Soc. Phycol. 9, 12-16 (1961). O, S (inkl. Cyanophyceae).

Salton, M. R., Microbial Cell Walls (John Wiley \& Sons, Inc., New York, London 1960). B (inkl. Anacystis, Microcoleus).

Saubert, S., GrobbelaAr, N., The Identification and Nitrogen Fixation of Some Free-Living Micro-Organisms from the Northern Transvaal, S. African J. Agric. Sci, 5, 283-292 (1962). PN.

Senior, V. E., Algal Poisoning in Saskatchewan, Can. J. Comp. Med. Vet. Sci. 24, 26-31 (1960). O.

Shatкin, A. J., A Chlorophyll-Containing Cell Fraction from the Blue-Green Alga, Anabaena variabilis, J. Biophys. Biochem. Cytol. 7, 583-584 (1960). B.

Sirenko, L. A., Bohdanova, T. L., Stimulation of Anabaena variabilis Culture Development with Physiologically Active Substances, Visnyk Kyyrvs'koho Univ. No. 5, Ser. Biol. 2, 7-9 (1962), russisch. P.

Smirnov, N. N., Feoktisova, O. I., The Toxicity of Blue-Green Algae, Trans. Inst. Biol. Vodokhranilishch Akad. Nauk. S.S.S.R. 5, 10-12 (1963), russisch. O.

Sмгтн, C. E., Jr., A Comparative Investigation of Some Physiological Activities of Seven Species of Chroococcacean Algae, Ecology of Phytoplankton Blooms, Progress Report II, Potamological Institute, Louisville, Kentucky (1963). P.

Sмiтн, D. C., Studies in the Physiology of Lichens. I. The Effects of Starvation and of Ammonia Absorption Upon the Nitrogen Content of Peltigera polydactyla, Ann. Bot. [n.s.] 24, 52-62 (1960). $\mathrm{P}$.

Smith, D. C., Studies in the Physiology of Lichens. II. Absorption and Utilization of Some Simple Organic Nitrogen Compounds by Peltigeva polydactyla, Ann. Bot. [n.s.] 24, 172-185 (1960). P.

Sмгтн, D. C., Studies in the Physiology of Lichens. III. Experiments with Dissected Discs of Peltigera polydactyla, Ann. Bot. [n.s.] 24, 186-199 (1960). P.

SMith, R. F., FUller, W. H., The Effect of Certain Components of Ionized Air on the Growth and Movement of Microcoleus vaginatus, J. Arizona Acad. Sci. 2, 20-23 (1961). P.

Sorenson, L. O., Conover, J. T., Algal Mat Communities of Lyngbya confervoides (C. Agardh) Gomont, Publ. Inst. mar. Sci. Univ. 'Texas 8, 61-74 (1962). O.

Stanier, R. Y., van Niel, C. B., The Concept of a Bactevium, Arch. Microbiol. 42, 17-35 (1962). S.

Stein, J. R., Morphological Variation of a Tolypothrix in Culture, Brit. Phys. Bull, 2, 206-209 (1963). M.

TAHA, M. S., The Effect of the Hydrogen Ion Concentration in the Medium and of Temperature on the Growth and Nitrogen Fixation by Blue-Green Algae, Mikrobiologiya 32, $968-972$ (1963), russisch. PN.

Talpasayi, E. R. S., Johannesbaptista pellucida from Andra Pradesh, Curr. Sci. 31, 299-300 (1962). S.

Talpasayi, E. R. S., Localisation of Acid Phosphatase in Anabaena cylindrica Lemm., Curr. Sci. 31, 430-431 (1962). C.

Talpasayi, E. R. S., Polyphosphate Containing Particles of Blue-Green Algae, Cytologia, 28, 76-80 (1963). C.

Thom as, J. B., Shape of the Red Absorption Band of Chlorophyll a in Algae Lacking Chlorophyll b, Colloque Int. Ctr. Natl. Rech. Sci. 119, 288-299 (1963). P.

Umezaki, I., Key to the Genera of Cyanophyta, Bull. Jap. Soc. Phycol, 11, 70-78 (1963). S.

VAsishta, P. C., Two New Species of Phormidium, J. Indian bot. Soc. 41, 64-67 (1962). S.

VAsishta, P. C., Some New Records of the Genus Calothrix Ag. from Hoshiarpur, J. Indian bot. Soc. $41,510-515$ (1962). S.

VAsishta, P. C., Some Observations on the Life History of Rivularia joshii sp. nov. from Hoshiarpur, Punjab, India, J. Indian bot. Soc. 41, 516-523 (1962). M.

Webber, E. E., Nostoc parmelioides in Massachusetts, Rhodora 64, 358-360 (1962). O.

Whitford, L. A., Notes on the Ecology of Some Species of Algae, Phyc. Soc. Am. News Bull. 13, 68 (1960). O.

Whit ton, B. A., Effect of Deep-Freeze Treatment on Blue-Green Algal Cultures, Brit. phycol. Bull. 2 (3), 177-178 (1962). P.

WiLd, H., Harmful Aquatic Plants in Africa and Madagascar, Kirkia 2, 1-66 (1961). O (inkl. Microcystis). 
Wilson, P. W., Burris, R. H., Fixation of Nitrogen by Cell-Free Extracts jrom Micro-Organisms, Science 131, 1321 (1960). PN.

Wütririch, M., Note sur l'apparition d'A phanizomenon flos-aquae (L.) Ralts. dans le lac de Neuchâtel, Bull. Soc. Neuchâteloise Sci. Nat. 85, 103-108 (1962). O.

Ziegler, I., Di-und Tetrahydropierin bei der Blaualge Anacystis nidulans, Biochem. Z. 337, 62-68 (1963). B.

\section{Ergänzungen zur Blaualgenliteratur aus den Jahren 1964-1966}

Aaronson, S., Hutner, S. H., Biochemical Markers and Microbial Phylogeny, Quart. Rev. Biol. $41,13-46$ (1966).

AнL, T., WiLlêN, T., Glimtar Från Svensk Forskning Mälarundersökningen - en presentation [The Lake Mälaren Research - an Introduction] (Statens Naturvetensk. Forskningsråd, Stockholm, 1965), schwedisch. O.

Aкгу ама, M., Some Soil Algae from Japan, Shimane Univ., Natural Sci. No. 15, 96-117 (1965). O. (inkl. Cyanophyceae).

Amesz, J., Spectrophotometric Evidence for the Participation of a Quinone in Photosynthesis of Intact Blue-Green Algae, Biochim. Biophys. Acta 79, 257-265 (1964). P.

AmmeraAl, R. N., Vennesland, B., Effect of $\mathrm{CO}_{2}$ and $\mathrm{HCN}$ on the Quinone Hill Reaction with Anabaena variabilis, Arch. Biochem. biophys. 117, 429436 (1966). P.

Anagnostipis, K., Golubić, S., Über die Öhologie einiger Spirulina-Arten, Nova Hedwigia 71 (1-4), 309-335 (1966). O.

Antia, N. J., Kalmakofe, J., Growth Rates and Cell Yields from Axenic Mass Cultures of Fourteen Species of Marine Phytoplankters, Fisheries Research Board of Canada, Manuscript Report Series (Oceanographic and Limnological) No. 203 (1965). P (inkl. Agmenellum, Anacystis).

Antta, N. J., Kalmakoff, J., Watt, A., Enolase Activity in Marine Planktonic Algae, Can. J. Biochem. 44, 449-454 (1966). P.

ARChibALD, C. G. M., Some New and Interesting Cyanophytes from the Kowie River System in the Eastern Cape Province (South Atrica), Nova Hedwigia 12, 529-538 (1966). S.

Armstrong, N. E., Odum, H. T., Photoelectric Ecosystem, Science 143, 256-258 (1964). O.

Banlen, C. van, Aldolase in Blue-Green Algae, Nature 206, 193-195 (1965). B.

BAalen, C. van, Quantitative Surface Plating of Coccoid Blue-Green Algae, J. Phycol. 1, 19-22 (1965). P.

Baflen, C. Van, Mutation of the Blue-Green Alga, Anacystis nidulans, Science, N. Y. 149,70 (1965). $\mathrm{P}, \mathrm{S}$.

Barghoorn, E. S., TyLER, S. A., Micro-Organisms trom the Gunflint Chert, Science 747, 563-577 (1965). O,S.

Bendre, A. M., AGariser, M. S., Myxophyceae of Bhopal and its Environs, Phykos 4, 76-82 (1965). S.

Berns, D. S., Edwards, M. R., Electron Micrographic Investigations of c-Phycocyanin, Arch. Biochem. Biophys. 110, 511-516 (1965). Cu.

BIcudo, C. E. DE M., The Genus Borzia Cohn ex Gom. in Săo Paulo, Brazil, Rickia 2, 147-152 (1965). S.

Biebl, R., Kusel-Fetzmann, E., Beobachtungen über das Vorkommen von Algen an Thermalstandorten auf Island, Oesterr. bot. Z. 113, 408-423 (1966). S.

Biswas, S., Oxygen and Phytoplankton Changes in the Newly Forming Volta Lake in Ghana, Nature 209, 218-219 (1966). O.

Boucher, L. J., Optical Rotatory Dispersion of Phycocyanin, Biochem. 5, 3796-3802 (1966). B.

Bowen, C. C., Jensen, T. E., Blue-Green Algae: Fine Structure of the Gas Vacuoles, Science 147. $1460-1462$ (1.965). Cu.

Bringmann, G., KüHn, R., Der Biomassetiter von Escherichia, Scenedesmus und Nostoc als Ausdruck der biologisch wirksamen Beschaffenheit des Wassers, Ges.-Ing. 87, 222-230 (1966). K.

Brown, R. M., Smith, K. M., Walne, P. L., Replication Cycle of the Blue-Green Algal Virus LPP-1, Nature 212, $729-780$ (1966). B.

Brzin, B., Dependence of the Cell Morphology of Vitreoscilla on the Temperature on Incubation, Experientia 22, 804 (1966). 
Calef, G. W., Grice, G. D., Relationship Between the Blue-Green Algal Trichodesmium thiebautii and the Copepod Macrosetella gracilis in the Plankton of the Northeastern South America, Ecology 47,855 (1966). O.

Cameron, R. E., Blank, G. B., Desert Algae: Soil Crusts and Diaphanous Substrata as Algal Habitats, National Aeronautics and Space Administration Technical Report No. 32-971 (1966). O.

Canter, H. M., Studies on British Chytrids. XXIV. Entophlyctis molesta sp. nov., Parasitic on Siylosphaeridium stipitatum (Bachm.) Geitler et Gimesi from the Plankion, J. Roy. Microscopical Soc. 84, 549-557 (1965). O (inkl. Gomphosphaeria).

CARr, N. G., The Occurrence of Poly- $\beta$-Hydroxybutyrate in the Blue-Green Alga, Chlorogloea fritschii, Biochim. Biophys. Acta 120, 308-310 (1966). B.

Carr, N. G., Hallaway, M., The Presence of $\alpha$-Tocopherolquinone in Blue-Green Algae, Biochem. J. $97,9 \mathrm{c}-10 \mathrm{c}(1965)$. B.

Carr, N. G., Hallaway, M., Reduction of Phenolindo-2,6-Dichlorophenol in Davh and Light by the Blue-Green Alga, Anabaena variabilis, J. gen. Microbiol. 39, 335-344 (1965). B.

Castenholz, R. W., Environmental Requirements of Thermophilic Blue-Green Algae, Proceedings of the Symposium on the Environmental Requirements of Bhe-Green Algae (University of Washington 1966). O.

Chan, K. L., SAunders, L. G., Forciponyia (Dacnoforcipomyia) anabaenae, a New Blood-Sucking Midge from Singapore, Described in All Stages (Diptera, Ceratopogonidae), Can. J. Zool. 43, 527-540 (1965). O (inkl. Anabaena, Oscillatoria).

Chandhyor, M. S., A New Species of Anabaenopsis (A. venkataramanii sp. nov.) from India, Hydrobiologia 27, 323-327 (1966). S.

Chapman, D. J., The Pigments of the Symbiotic Algae (Cyanomes) of Cyanophora paradoxa and Glaucocystis nostochinearum and Two Rhodophyceae, Porphyridium aerugineum and Asterocystis ramosa, Arch. Mikrobiol. 55, 17-25 (1966). B.

Cheung, W. Y., GiBbs, M., Dark and Photometabolism of Sugars by a Blue-Green Alga: Tolypothrix tenuis, Plant Physiol. 41, 731-737 (1966). P.

Cloud, P. E., Significance of the Gunflint (Precambrian) Microflora, Science 148, 27-35 (1965).

Cox, R. M., FAY, P., FogG, G. E., Nitrogen Fixation and Photosynthesis in a Subcellular Fraction of the Blue-Green Alga Anabaena cylindrica, Biochim. biophys. Acta 87, 208-210 (1964). PN.

CribB, A. B., The Algae of Heron Island, Great Barrier Reef, Australia, University of Queensland Papers (Heron Island Research Station) 7(1), 3-23 (1966). S.

Davis, C. C., A Preliminary Report on the Effects of Indolacetic Acid and Gibberellic Acid Upon the Growth of Planktonic Algae Under Semi-Field Conditions, Verh. int. Verein. Limnol. 15, 811-816 (1.964). O.

Davis, E. B., Tischer, R. G., Photochemical Reduction of Elemental Nitrogen by Anabaena flosaquae A-37, Nature 212, 302-303 (1966). PN.

DAvis, E. M., Degradation and Assimilation of Condensed Phosphates by Blwe-Green and Green Algae, Thesis, University of Oklahoma, 140 pp., Diss. Abstr. [B] 27, 1179 (1966). P.

Denisova, O. I., MaISTRenko, Y. M., Role of Blue-Green Algae in Formation of the Hydrochemical Conditions in the Kakhovka Reservoir, Ekol i Fizziol. Sinezelen. Vodoroslei Sb. 1965, 95-100. O.

Dor, I., Algae from Tiberian Hot Springs, Proc. Bot. Soc. Israel, p. 202 (1965). S, O.

Draganov, S. J., Untersuchungen ïber die Algenflora der Böden Bulgariens. II. Verbreitung von Nostoc commune Vauch. auf Bodentypen, Ann. Univ. Sofia, Facult. Biol. 58, 123-129 (1965), bulgarisch mit russischer und deutscher Zusammenfassung. $\mathrm{O}, \mathrm{S}$.

Draganov, S. J., Genova, E. M., Untersuchungen über die Algenflora dev Böden Bulgariens. III. Vertikale Verbreitung der Blaualgen an den Nordabhängen des Vitoscha-Gebirges, Ann. Univ. Sofia, Facult. Biol. 59, 153-163 (1966), bulgarisch mit russischer und deutscher Zusammenfassung. $\mathrm{O}, \mathrm{S}$.

Draganov, S. J., Vičeva, A. K., Boden-Blanalgen aus dem Botanischen Garten der Sofioter Universität, Ann. Univ. Sofia, Facult. Biol. 59, 27-34 (1966), bulgarisch mit russischer und deutscher Zusammenfassung. O, S.

Drew, E. A., Sмiтh, D. C., The Physiology of the Symbiosis in Peltigera polydactyla (Neck.) Hotfm. Lichenologist 3(2), 197-201 (1966). P.

Drum, R. W., Pankratz, S., Fine Structure of an Unusual Cytoplasmic Inclusion in the Diatom Genus, Rhopalodia, Protoplasma 60, 141-149 (1965). Cu. 
Dugdale, R. C., Goering, L. J., Ryther, J. H., High Nitrogen Fixation Rates in the Sargasso Sea and the Arabian Sea. Limnol. Oceanogr. 9, 507-510 (1964). PN.

Dugdale, V. A., Aspects of the Nitrogen Nutrition of Naturally Occurring Populations of Phytoplankton Dominated by Blue-Green Algae, aus: Proceedings of the Symposium on the Environmental Requirements of Blue-Green Algae (University of Washington 1966). PN.

Eberly, W. R., Problems in the Laboratory Culture of Planktonic Blue-Green Algae, aus: Proceedings of the Symposium on the Environmental Requirements of Blue-Green Algae (University of Washington 1966). K.

Echlrn, P., The Cyanophytic Origin of Higher Plant Chloroplasts, Brit. phycol. Bull. 3(1), 150-151 (1966). Cu.

Echlin, P., The Fine Structure of Glaucocystis nostochinearum in Relation to the Cyanophytic Origin of Chloroplasts, 6th Int. Congress Electron Microscopy, Kyoto pp. 285-286 (1966). Cu.

Echlin, P., Origins of Photosynthesis, Science J. 2(4), 42-47 (1966).

Edmondson, W. T., Why Study Blue-Green Algae? Aus: Proceedings of the Symposium on the Environmental Requirements of Blue-Green Algae (University of Washington 1966).

Evans, J. H., Some New Records and Forms of Algae in Central East Africa, Hydrobiologia 20 , 59-86 (1962). S (inkl. Anabaenopsis).

FAy, P., Cox, R. M., Decarboxylation Performed by Particulate Fractions of Two Nitrogen-Fixing Blue-Green Algae, Biochim. biophys. Acta 126, 402-404 (1966). P.

Fenwick, M. G., Some Rare and Interesting Algae from Fort Radium, N.W.T., Canada, Trans. Amer. Microsc. Soc. 85, 477-480 (1966). S.

Fitzgerald, G. P., Use of Potassium Permanganate for Control of Problem Algae, J. Am. Water Works Ass. 58, 609-614 (1966). O.

Fitzgerald, G. P., Nelson, T. C., Extractive and Enzymaitic Analyses for Limiting or Surplus Phosphorus in Algae, J. Phycol. 2(1), 32-37 (1966). P.

Flint, E. A., Toxic Algae in Some New Zealand Freshwater Ponds, New Zealand Vet. J. 14, 181-185 (1966). O.

Foerster, J. W., The Use of Calcium and Magnesium Hardness Ions to Stimulate Sheath Formation in Oscillatoria limosa (Roth.) C. A. Agardh, Trans. Amer. Micros. Soc. 83, 420-427 (1964). P.

FogG, G. E., The Extracellular Products of Algae, in: Oceanography and Marine Biology, Bd. 4 (George Allen \& Unwin Ltd., London 1966). P, O.

Fogg, G. E., Nalewajko, C., Watt, W. D., Extracelluiar Products of Phytoplankton Photosynthesis, Proc. Roy. Soc. [B] 762, 517-534 (1965). P, O.

Fogg, G. E., Stewart, W. D. P., Nitrogen Fixation in Blue-Green Algae, Sci. Progr. 53, 191-201 (1965). P.

Fogg, G. E., Patthaik, H., The Release of Extracellular Nitrogenous Products by Westiellopsis prolifica Janet, Phykos 5, 58-67 (1966). P.

Forest, H. S., Weston, C. R., Blue-Green Algae from the Atacama Desert of Northern Chile, J. Phyc. 2, 163-164 (1966). S.

FredrICK, J. F., The Origin of the Multiple Forms of Phosphorylase in Algae, Ann. N. Y. Acad. Sci. 121, 634-639 (1964). B.

FREDrick, J. F., Polyacrylamide Gel Studies of the Isozymes Involved in Polyglucoside Synthesis in the Algae, Phyton Rev. Int. Bot. Exp. 21, 85-89 (1964). B.

Fredricks, W. W., Jagendorf, A. T., A Soluble Component of the Hill Reaction in Anacystis nidulans, Arch. Biochem. Biophys. 104, 39-49 (1964). B.

Freytet, P., Plaziat, J.-C., Importance des constructions algaives dues à des Cyanophycés dans les formations continentales du Cretace supérieur, Bull. Soc. Géol. de France, 7, 679-694 (1966). V.

Funs, G. W., Spherical Subunits in Photosynthetic Membranes of Two Cyanophyceae and the Bacterium Rhodospirillum rubrum, Arch. Mikrobiol. 54, 253-265 (1966). Cu.

FUjImori, E., Pecci, J., Dissociation and Association of Phycocyanin, Biochemistry 5(11), 35003508 (1966). B.

Funahashi, S., Marine Algae from Vladivostok and its Vicinity, Bull. Jap. Soc. Phycol. 14, 127148 (1966). O, S (inkl. Cyanophyceae).

GapochkA, L. D., Maximov, V. N. et al., The Influence of Certain Sugars, when Present Simultaneously, on the Yield of Anacystis nidulans Algae as Studied by the Method of Casual Balance, Doklady AN SSSR 170, 956 (1966). P. 
Geitler, L., Cyanophanon minus n. sp., Österr. Bot. Z. 173, 460-463 (1966). S.

Gerasimenko, L. M., Morphological and Cytological Changes Occurving in Some Algal Species Exposed to the Action of Colchicine, Chlortetracycline and Trypaflavine (Acriflavine Hydrochloride), Mikrobiologiya 34, 851-857 (1965), russisch. M.

Gerhardt, B., Trebst, A., Photosynthetische Reaktionen in lyophilisierten Zellen der Blaualge Anacystis, Z. Naturforsch. [B] 20(9), 879-884 (1965). P.

Gerhardt, B., Santo, R., Photophosphorylierung in einem zellfreien System aus Anacystis, $Z$. Naturforsch. [B] 21 B, 673 (1966). B.

Ghosh, A. K., Govindjee, Transfer of the Excitation Enevgy in Anacystis nidulans (Cyanophyta) Grown to Obtain Different Pigment Ratios, Biophys. J. 6(5), 611-619 (1966). P.

Godnev, T. N., Rotfarb, R. M., Gvardian, V. N., On the Participation of Protoporphyrin and Hematin in the Biosynthesis of Phycocyanin, Doklady AN SSSR 169, 1191 (1966). B.

Goedheer, J. C., Birnie, F., Fluorescence Polarisation and Location of Fluorescence Maxima of C-Phycocyanin (from Synechococcus cedrorum), Biochim. biophys. Acta 94, $579-581$ (1965). B.

Goering, J. J., Nitrogen Fixation in Two Wisconsin Lakes, Limnol. Oceanogr. 9, $530-539$ (1964). O.

Goering, J. J., Dugdale, R. C., Menzel, D. W., Estimate of in Situ Rates of Nitrogen Uptake by Trichodesmium sp. in the Tropical Atlantic Ocean, Limnol. Oceanogr. 11, 614-620 (1966). O.

Goyal, S. K., Venkataraman, G. S., Cultural Variations in the Morphology of Anabaena cycadeae Reinke, Phykos 3, 35-36 (1964). M.

Goyal, S. K., Venkataraman, G. S., Stimulating Effect of Some Cellular Components of Alternaria sp. Upon the Growth of a Nostoc Strain, Curr. Sci. 34, 152-153 (1965). P.

GrUiA, L., Xenococcus irregularis Gruia n. sp., A New Terricolous Cyanophyceae, Revista Biol. 5 , 213-216 (1966). S.

Gupta, A. B., Role of Subterranean Myxophyceae in Rice Fields, Lab. Dev., India, 2, 42-43 (1964). O.

Gupta, A. B., Lata, K., Effect of Algal Growth Hormones on the Germination of Paddy Seeds, Hydrobiologia 24, 430-434 (1964). O.

Gupta, A. B,, Shrivastava, G. C., On Antibiotic Properties of Some Fresh Water Algae, Hydrobiologia 25, 285-288 (1965). O.

Gup's, A. B., Shukla, A. C., The Effect of Algal Hormones on the Growth and Development of Rice Seedlings, Lab. Dev., India 2(3), 204 (1964). O.

Gupja, D., Some New Record of Blue-Green Algae from West Bengal, Bull. Bot. Soc. Bengal 19, 1-2 (1965). S.

Gusev, M. V., Sravnitelnaja fiziologija sinëzelenych vodoroslej. [Vergleichende Physiologie der Blaualgen], Uspechi Mikrobiologii 3, 74-103 (1966), russisch. P.

Gusev, M. V., Fedorov, V. D., Uglerodistoje pitanije fotosintézirujuščcich bakterij i vodoroslej. [Kohlenstoffernährung der photosynthetisievenden Bakterien und Algen], Bjul. Mosk. ob-va ispyt. prirody, Otd. biol. 77, 155-156 (1966), russisch. P.

Guseva, K. A., Goncharova, S. P., Intluence of Ultraviolet Light on the Growth of Blue-Green Algae, Trudy Inst. Biol. vnutr. Vod. 11, 81-86 (1966), russisch. P.

Halperin, D. R. DE, Cyanophyta nuevas pava la Avgentina, Darwiniana 13, 115-137 (1964). S.

Hall, W. T., Claus, G., The Fine Structure of the Coccoid Blue-Green Alga, nom. Prov. Synechococcus oceanica, Rev. Biologia 5, 63-74 (1964/65). Cu.

Hattori, A., Effects of Side-Chain Deutevation on Protein Stability, Biochemistry 4(7), 1213-1225 (1965). B.

Hattori, A., Crespr, H. L., Katz, J. J., Association and Dissociation of Phycocyanin (from Plectonema calothricoides) and the Effects of Deuterium Substitution on the Processes, Biochemistry $4(7), 1225-1238$ (1965). B.

Hattori, A., Myers, J., Reduction of Nitrate and Nitrite by Subcellular Preparations of Anabaena cylindrica, Plant Physiol. 41, 1031-1036 (1966). B.

Hegrash, A. K., Matvienko, S. O., Algicidal Properties of Aquatic and Shore Plants of the Kremenchuy Reservoir with Respect to the Blue-Green Algae Microcystis pulvevea and Anabaena hassalii, Mikrobiol. Zh. Akad. Nauk. Ukr. RSR 27(2), $39-42$ (1965), ukrainisch. O.

Hiramatsu, N., Blue-Green Algae of Nagasaki Prefecture (1), J. Yukokan High School, Nagasaki Pref., p. 1-9 (1964). S.

Hirano, M., Freshwater Algae in the Antarctic Regions, aus: P. van Oye and J. van Mieghem, Biogeography and Ecology in Antarctica (1965). S. 
Hoare, D. S., Honre, S. K., Feedback Regulation of Arginine Biosynthesis in Blue-Green Algae and Photosynthetic Bacteria, J. Bact. 92, 375-379 (1966). B.

Höcht, H., MaRTin, H. H., KAndleR, O., Zur Kenntnis der chemischen Zusammensetzung der Zellwand der Blaualgen, Z. Pflanzenphys. 53, 39-57 (1965). B.

Hoek, C., van den, Donze, M., The Algal Vegetation of the Rocky Côte Basque (SW France), Bull. Centre Etud. Rech. Sci., Biarritz, 6, 289-319 (1966). O.

Hofsten, A. V., Pearson, L. C., Chromatin Distribution in Cyanophyceae, Hereditas 53, 212-220 (1965). C.

Holm-Hansen, O., Viability of Lyophilized Algae, Can. J. Bot. 42, 127-137 (1964). P.

Holm-Hansen, O., Recent Advances in Physiology of Blue-Green Algae, aus: Proceedings of the Symposium on the Environmental Requirements of Blue-Green Algae (University of Washington 1966). P.

Holm-Hansen, O., Lewin, R. A., Bound Ornithin in Certain Flexibacteria and Algae, Phys. Plant. $78,418-423(1965)$. B.

Holm-Hansen, O., Prasad, R., Lewin, R. A., Occurrence of $\alpha, \varepsilon$-Diaminopimelic Acid in Algae and Flexibacteria, Phycologia 5, 1-14 (1965). B.

Holton, R. W., Blecker, H. H., Onore, M., Effect of Growth Temperature on the Fatty Acid Composition of a Blue-Green Alga, Phytochem. 3, 595-602 (1964). B.

Hrbacer, J., Contribution to the Ecology of Water-Bloom-Forming Blue-Green Algae - Aphanizomenon flos-aquae and Microcystis aeruginosa, Verh. Int. Ver. Limnol. 15, 837-846 (1964). O.

JAvornický, P., Measurements of Production and Turnover of Phytoplankton in Four Localities of Poland, Ekologia Polska [A] 14, 203-214 (1966). O.

J AvorNick'́, P., Seasonal Dynamics of the Phytoplankton of Slapy Reservoir 1958-7960, Hydrobiol. Stud. 1, 155-163 (1966). O.

Johnson, G. V., Mayeux, P. A., Evans, H. J., A Cobalt Requirement for Symbiotic Growth of Azolla filiculoides in the Absence of Combined Nitrogen, Plant. Physiol. 47, $852-855$ (1966). P.

JoNes, K., The Extracellular Nitrogen of the Marine Blue-Green Alga, Calothrix scopulorum, Brit. Phyc. Bull. 3, 153 (1966). P.

Jones, L. W., Myers, J., Pigment Variations in Anacystis nidulans Induced by Light of Selected Wavelengths, J. Phyc. 1, 7-14 (1965). B.

Kamat, N. D., The Oscillatoriaceae of Ahmedabad, India, J. Univ. Bombay 37, $20-27$ (1964). S.

KANG, J. W., On the Geographical Distribution of Marine Algae in Korea, Bull. Pusan Fish. Coll. 7, 1-125, (1966). S. O (inkl. Cyanophyceae).

Kann, E., Der Algenaufreuchs in einigen Bächen Österveichs, Verh. Int. Verein. Limnol. 76, 646-654 (1966). O.

KE, B., Light-Induced Absorption-Change Transients in Some Blue-Green Algae, Nature 203, 405 (1964). P.

Kæ, B., NGo, E., Light-Induced Rapid Absorption Changes During Photosynthesis. VI. Complex Reactions in Some Blue-Green Algae, Biochim. biophys. Acta 109, 431-447 (1965). P.

Kemp, H. T., Fuller, R. G., Davidson, R. S., Potassium Permanganate as an Algicide, J. Am. Water Works Ass. 58, 255-263 (1966). O.

Kenneth, M., Smith, Brown, R. M., Walne, P. L., Goldstein, D. A., Electron Microscopy of the Infection Process of the Blue-Green Alga Virus, Virology 30, 182-192 (1966). Cu.

KNyzhnук, Zн. P., Dynamics of the Development of Blue-Green Algae and Bacteria in the Ponds in the Vicinity of Kiev, Mikrobiol. Zh. Akad. Nauk. Ukr. RSR 26(5), 31-36 (1964), ukrainisch O.

Косн, W., Cyanophyceen, Kulturen, Anveicherungs- und Isolier-Verfahren, CfB 1 Orig. Suppl. H. 1 , Abt. Referate, 415-431 (1965). K.

Kohl, D. H., Townsend, J., Commoner, B., Crespi, H. L., Dougherty, R. C., Katz, J. J. Effects of Isotopic Substituation on Electron Spin Resonance Signals in Photosynthetic Organisms, Nature 206, 1105-1110 (1965). B.

Konst, H., McKercher, P. D., Gorham, P. R., Robertson, A., Howell, J., Symptoms and Pathology Produced by Toxic Microcystis aeruginosa NRC-1 in Laboratory and Domestic Animals, Can. J. Comp. Med. Vet. Sci. 29, 221-228 (1965). PT.

Kordjum, V. A., Ratusnaja, M. J. et al., O mineralnom pitanii Anabaena variabilis. Über die Minevalsalzernährung von Anabaena variabilis, Mikrobiol. Z. 28, 58-62 (1966), russisch. P. 
Kovaleva, N. G., Fiziologo-biochimičeskije osobennosti Anabaena variabilis v svjazi s voprosami jejo kultivirovanija. [Physiologisch-biochemische Eigenschatten von Anabaena variabilis in Beziehung zu den Fragen ihrev Kultivierung], Autoref. Diss. LGU (1966), russisch. K, P.

Kowallik, U., Pringsheim, E. G., The Oxidation of Hydrogen Sulfide by Beggiatoa, Amer. J. Bot. 53, 801 (1966). B.

Kraus, M. P., Preparation of Pure Blue-Green Algae, Nature 271, 310 (1966). K.

Kučkarova, M. A., Maksudov, T. U., Chodžajeva, Voropajeva, O. G., Izyskanije $i$ otbor fiksatovov azota iz cisla sinězelenych vodoroslej risovych polej Sredněj Azii. [Isolierung stickstoffixierender Blaualgen aus Reisfeldern Zentralasiens.] - Sb. Matěrialy zakavkazsk. konf. po sporovym rastěnijam, Baku, AN Azerb. SSR, 55-57 (1965), russisch. P.

Kunnemann, O., Floraciones acuaticas y nivales ocasionadas por algas, Anal. Soc. cient. Argentina 153, 3-48 (1965). O, S.

Kusın, B. S., Ökologie und Physiologie von Blaualgen und anderen Wasserpflanzen in Stauseen. I. Gesetzmässigkeiten des Massenautretens von Blaualgen in Gewässern, Vlg. Nauka 1,272 S. (1965), russisch. $\mathrm{O}, \mathrm{P}$.

Kusin, B. S., Orkologie und Physiologie von Blaualgen und anderen Wasserplanzen in Stauseen. II. Die Vegetation der Wolga-Stauseen, Vlg. Nauka 2, 209 S. (1966), russisch. O, P.

Lancaster, L. J., Bowman, Th. E., A Bloom of the Planktonic Blue-Green Alga, Trichodesmium erythraeum, in the Tonga Islands, Limnol. Oceonogr. 10, 291-293 (1965). O.

LAwson, G. W., Additions to a Preliminary Check-List of Ghanaian Fresh-and Brackish-Water Algae, West African Science Ass. 10, 45-55 (1965). S.

Lazaroff, N., Photoinduction and Photoreversal of the Nostocaceae Delevopmental Cycle, J. Phyc. 2, 7-16 (1966). P.

LEFORT, M., Sur le chromatoplasma d'une Cyanophycée endosymbiotique : Glaucocystis nostochinearum Itzigs., C. R. Acad. Sci. Paris 261, 233-236 (1965). Cu.

Leo, R. F., PARker, P. L., Branched-Chain Fatty Acids in Sediments, Science 752,649-650 (1966). B.

Levin, E., Lennarz, W. J., Bloch, K., Occurrence and Localization of $\alpha$-Linoleic Acid Containing Galactolipids in the Photosynthetic Apparatus of Anabaena variabilis, Biochim. biophys. Acta 84 , $471-474$ (1964). B.

LewIs, J., Silicon Metabolism in Diatoms. V. Germanium Dioxide, a Specific Inhibitor of Diatom Growth, Phycologia 6, 1-12 (1966). P (inki. Phormidium, Lyngbya, Plectonema).

Maclean, F. I., Forrest, H. S., Myers, J., Origin of the Side-Chain in Pteridines of the Biopterin Type, Biochem. Biophys. Res. Commun. 18(4), 623-626 (1965). B.

Maloney, T. E., Toxicity of a Microcystis Waterbloom from an Ohio Pond, Ohio J. Sci 66, 514-517 (1966). PT.

Maugrni, E., Contributo alla conoscenza citologica di Nostoc commune Vaucher con particolare riguardo all'ultrastruttura, Caryologia 19, 267-298 (1966). Cu.

Mayland, F. H., McIntosh, T. H., Availability of Biologically Fixed Nitrogen-15 to Higher Plants, Nature 209, 421-422 (1966). O.

MerežKo, O. I., BeREzA, V. D., Vpliv dějakich organiennich preparativ na gazoobmin sino-zelenich vodorostéj [Einfluss einiger organischer Präparate auf den Gasaustausch der Blaualgen], Biol. Morfol. Ukr., Kiev, p. 174-175 (1966), ukrainisch. P.

Milova, S. N., K izuČeniju toksixnosti nekotorych planktonnych sine-zelenych vodoroslej Dneperskovo kaskada vodochranilišč [Zur Untersuchung der Toxizität einiger Planktonblaualgen in der Kaskade der Wasserveservoire des Dniepr], Gidrobiol. Z. 2, 49-53 (1966), russisch. O.

Milova, S. M., Eksperimentalne viznacennia vmistu vitaminu $B_{12}$ ta toksiunich recovin $u$ sinozelenich vodorostej. [Experimentelle Feststellung des Gehalts an Vitamin $B_{12}$ und toxischer Stoffe bei Blaualgen], Biologija i morfologija rib ta sanitarno-biologicnij režim prisnich vodojm, Kiev, p. 179-182 (1966), ukrainisch. B.

Mitra, A. K., Fuvther Studies on the Effect of Concentration of Nitrogenous Salts on the Formation of Heterocysts in the Cyanophyta, Proc. Nat. Acad. Sci. India 35, 1, 110 (1966). P.

Mitra, A. K., PANdey, D. C., On a New Genus of the Blue-Green Alga Chlorogloeopsis with Remarks on the Production of Heterocysts in the Alga, Phykos 5, 106-114 (1966). M. S.

Moore, B. G., Tischer, R. G., Extracellular Polysaccharides of Algae: Effects on Life-Support Systems, Science 745, 586-587 (1964). B. 
Moore, B. G., Tischer, R. G., Biosynthesis of Extracellular Polysaccharides by the Blue-Green Alga Anabaena flos-aquae, Can. J. Microbiol. 17(6), 877-886 (1965). B.

Mori, M., Ecology and Evolution of the Thermal Algae, J. Soc. Kumamoto Memorial Plant Collectors, No. 14, 1-14 (1965). O (inkl. Cyanophyceae).

Moser-Rohrhorer, M., Der Anteil des Pilzes und der Alge am Autbau der Gallerte von Collema, Cesko Mykol. 19, 205-211 (1965). C.

NoDA, M., Kang, J. W., Notes on the Marine Algae of Woolyungdo Island in the Japan Sea, Bull. Jap. Soc. Phycol. 12, 39-43 (1964). O, S (inkl. Cyanophyceae).

Ó CARRA, P., Purification and N-terminal Analyses of Algal Biliproteins, Biochem. J. 94, 171-174 (1965). B.

Ó CARra, P., Ó нEоcha, C., Bilins Released from Algae and Biliproteins by Methanolic Extraction, Phytochemistry 5(5), 993-997 (1966). B.

О́ нЕосна, C., Biliproteins of Algae, Annual Review of Plant Physiology 16, 415-434 (1965). B.

Obuchova, V. M., Kosenko, E. P., Species Novae Anabaenopsis (Wolosz.) Miller, Bot. Mater. Berb. in-ta bot. An. Kaz. SSR 2, 74-85 (1964), russisch. S.

Oltean, M., Fragen des Naturschutzes der Algenflora Rumäniens, Ocrotirea Naturii 10, 65-69 (1966), rumänisch mit deutscher Zusammenfassung. V.

Parker, B. C., Diboll, A. G., Alcian Stains for Histochemical Localization of Acid and Sulfated Polysaccharides in Algae, Phycologia 6, 37-46 (1966). C.

Parker, P. L., Leo, R. F., Fatty Acids in Blue-Green Algal Mat Communities, Science 148, 373374 (1965). B.

Pearson, J. E., Kingsbury, J. M., Culturally Induced Variation in Four Morphologically Diverse Blue-Greens, Am. J. Bot. 53, 192-200 (1966). P.

Perminova, G. N., Tretjakova, A. H., Vzaimodějstvije někotorych potvennych vodoroslej s vyssimi vastěnijami [Wechselseitige Beziehungen zwischen einigen Bodenblaualgen und höheren Pflanzen], Materrialy I-j Kirovsk. obl. Konf. Naučno-techniceskogo obščestva selskogo choz., 113-114 (1964), russisch. O.

Perminova, G. N., Influence of Blue-Green Algae on the Growth of Soil Microorganisms, Mikrobiologiya 33, 472-476 (1965), russisch. O.

Peškov, M. A., Comparative Cytology of Blue-Green Algae, Bacteria and Actinomycetes, Moskva Nauka pp. 246 (1966), russisch. C.

Prasad, B. N., Srivastava, P. N., Camptylonema godwardii sp. nov. from India, Phykos 3, 41-45 (1964). S.

Prasad, B. N., Srivastava, P. N., Calothrix sphaevospora sp. nov, from Lucknow, Phylkos 4, 83-85 (1965). S.

Prasad, B. N., Srivastava, P. N., Thermal Algae from Himalayan Hot Springs, Proc. Nat. Inst. Sci., India [B] 31, 45-53 (1965). S.

PRÁT, S., Colectie de Alge Hepatice si Musci in culturi [Sammlung von Algen, Lebermoosen und Moosen in Kultur], Stud. cercet. Biol. [ser. bot.] 17, 229-236 (1965), rumänisch. K.

PrINGSHEIM, E. G., Zur Kenntnis von Leucothrix, einer Gattung farbloser Cyanophyceen. Kleine Mitteilungen über Algen und Flagellaten, Arch. Mikrobiol. 55, 226 (1966). P, S.

Prud'homme van Reine, W. F., van Den Hoek, C., Cultural Evidence for the Morphologic Plasticity of Entophysalis deusta (Meneghini) Drouet and Daily (Chroococcales, Cyanophyceae), Blumea 14, 277-283 (1966). M, S.

Prud'homme van Reine, W. F., van Den Hoek, C., Isolation of Living Algae Growing in the Shells of Molluscs and Barnacles with EDTA (Ethylenediaminetetvaacetic Acid), Blumea 14, 331-332 (1966). K.

Punnett, T., Derrenbacker, E. C., The Amino Acid Composition of Algal Cell Walls, J. gen. Microbiol. 44, 105-114 (1966). B.

Raftery, M. A., $O$ heocha, C., Amino-Acid Composition and C-Terminal Residues of Algal Biliproteins, Biochem. J. 94, 166-170 (1965). B.

Ramamurthy, V. D., Seshadri, R., Effects of Gibberellic Acid $(G A)$ on Laboyatory Cultures of Trichodesmium erythraeum (Ehr.) and Melosira sulcata (Ehr.), Proc. Indian Acad. Sci. [B] 64, 146-151 (1966). P.

RATHSACK, R., Strukturveränderungen in Blaualgenzellen nach Röntgenbestrahinng, Stud. biophys., Berlin 1, 221-228 (1966). P. 
Rzhanova, G. N., Gorbunova, S. V., Aminokislotnyi sostav sinezelenoi vodosli Phormidium uncinatum Gom., Mikrobiologiya 34, 268-272 (1965). B.

Safferman, R. S., Morris, M. E., Control of Algae with Viruses, J. Am. Water Works Ass. 56(9), $1217-1224(1964)$. O.

SaHAy, M. N., Nitrogen Uptake by the Rice Crop in the Experiments with Blue-Green Algae, Proc. Indian Acad. Sci. [B] 43, 223-233 (1966). O.

SĂLĂGEANU, N., Opyty po vyrašcivaniju vozdušnych vodoroslej [Untersuchungen zur Entwicklung von Luftalgen], Rev. roum. Biol. [ser. bot.] 10, 224-231 (1965), russisch. K.

Sato, S., Paranagua, M. N., Eskinazi, E., On the Mechanism of Red Tide of Trichodesmium in Recife, North-Eastern Brazil, with Some Considerations of the Relation to Human Disease, "Tamandare Fever", Recife 5-6, 7-49 (1966). O.

SCHNEPF, E., KосH, W., DeICHGRÄBER, G., Zur Cytologie und taxonomischen Einordnung von Glaucocystis, Arch. Mikrobiol. 55, 149 (1966). C, S.

Scholl, D. W., TAFt, W. H., Algae, Contributors to the Formation of Calcareous Tufa, Mono Lake, California, J. sed. Petrology 34, 309-319 (1964). V.

SchwaBE, G. H., Typische Blaualgenformationen, Zeiss-Informationen 50, 131-133 (1964). M.

Scort, E., Berns, D. S., Protein-protein Interaction. The Phycocyanin System, Biochemistry 4(12), 2597-2606 (1965). B.

Shearman, D. J., Skipwith, P. A. D'E., Organic Matter in Recent and Ancient Limestones and its Role in their Diagenesis, Nature 209, 1310 1311 (1965). V.

SHILo, M., Study on the Isolation and Control of Blue-Green Algae from Fishponds, Bamidgeh 17, 83-93 (1965). P, O.

Simburth, J. M., Conover, J. T., Slicks A ssociated with Trichodesmium Blooms in the Sargasso Sea, Nature 205, 830-831 (1965). O.

Singh, M., Morphology and Reproduction of a Form of Compsopogon hookeri, Phykos 3, 37-40 (1964). M.

Singh, R. N., Sinha, R., Genetic Recombination in a Blue-Green Alga, Cylindrospermum majus Kuetz., Nature 207, 782-783 (1965). P, S.

Singh, R. N., Sinha, R., Mutation and Recombination in Blue-Green Algae, aus: The Impact of Mendelism in Agricultuve, Biology and Medicine, pp. 405-430. Int. Symp. Indian Soc. Genet. Plant Breeding, Indian Agric. Res. Inst., New Delhi (1966). P, S.

SIRENko, L. A., O prožnosti sujazi chlorofila s belkom u nekotorych sine-zelenych vodoroslej. [Über die Festigkeit der Verbindung von Chlorophyll mit Protein bei einigen Blaualgen], Trudy fiziol. biochim. rastěnij II. Dokl. 2. respubl. konf. po fiziol, i genetike rastěnij, Tartu, 185, 420 (1966), russisch. $P$.

SIRENKo, L. A., Vlijanije zatemnenija na fotoassimilimijušcije pigmenty nekotorych sine-zelenych vodoroslej. [Einfluss der Dunkelheit auf die Photoassimilationspigmente einiger Blaualgen), Gidrobiol. Z. 2, 73-74 (1966), russisch. P.

Sirenko, L. A., Vpliv riznich fahtoriv na fikobilinovi jkompleks sino-zelenich vodorostej. [Einfluss verschiedener Faktoren auf den Phycobilin-Komplex der Blaualgen], Ukrajinskij bot. Z. 23, 3-8 (1966), ukrainisch. P.

Sirenko, L. A., Chernoyusova, V. M., Nesterenko, O. A., Biological Aspects of Mass Accumulations of Blue-Green Algae and the Possibility of Rational Utilization of their Biomass, Gidrobiol. Zh., Kiev 2(5), 71-73 (1966), russisch. O.

SmILlie, R. M., Isolation of Phytoflavin, a Flavoprotein with Chloropast Ferredoxin Activity, Plant Physiol. 40, 1124-1128 (1965). B.

Smith, D. C., DREw, E. A., Studies in the Physiology of Lichens. V. Translocation from the Algal Layer to the Medulla of Peltigera polydactyla, New Phyt. 64, 195-200 (1965). P.

Smith, K. M., Brown, R. M., Wayne, P. L., Goldstern, D. A., Electron Microscopy of the Infection Process of the Blue-Green Alga Virus, Virology 30, 182-192 (1966). CU.

Solly, W. W., A Bloom of the Alga Nodularia in Lake Wellington, Victoria, Newsl. Aust. Soc. Limnol. 5(2), 28-29 (1966). O.

Srivivasan, K. S., Algarum Species ex India Oriundae, Bull. Bot. Surv. India 7(1/4), 188-266 (1965). S.

Starmach, K., Algae on a Burnt-Out Earth, Fragm. florist. Geobot. 12, 519-521 (1966), polnisch, mit englischer Zusammenfassung. $O$. 
Starmach, K., Epilithic Algae in the Chocholowska Valley in the Tatra Mountains, Fragm. florist. Geobot. 12, 527-531 (1966), polnisch, mit englischer Zusammenfassung. O.

Stewart, W. D. P., Nitrogen Turnover in Marine and Brackish Habitats. I. Nitrogen Fixation, Ann. Bot., N.S., 29, 229-239 (1965). PN, O.

Stewart, W. D. P., Nitrogen Fixation in a Dune Slack, Brit. Phyc. Bull. 2(6), 514 (1965). PN, O.

Stewart, W. D. P., Nitrogen Fixation in Plants, pp. 168 (University of London, Athlone Press 1965). PN.

Śtina, E. A., Pankratova, E. M., Perminova, G. N., Tré́jakova, A. N., Jung, L. A., Učastije sinë-zelenych vodoroslej v nakoplenii azota v počve. [Die Rolle der Blaualgen bei der Stickstoffanhäufung im Boden], Tezisy dokladov IX Meždunar. Kongr. Mikrobiol,, Izd. «Medicina», M: 277-278 (1966), russisch. O, P.

Ština, E. A., Vajramova, L. A., Perminova, G. H., Trefjakova, A. N., Vzaimodějstvije meżdu počvennymi vodovosljami i vysšimi rastěnijami. [Beziehungen zwischen den Bodenalgen und höheren Pflanzen], Sb. "Fizika, Chimija, Biologija i Miněrologija počv,» (Dokl. k US Meždun. Kongr. počvovědov), izd. "Nauka», M: 284-292 (1964), russisch. O.

SubBa Raju, N., Aulosira terrestre sp. nov. Occurving in the Soils of Hyderabad (India), Phykos $3(1 / 2), 33-34(1964)$. S.

Subbaramaiah, K., Doshx, Y. A., Growth of Blue-Green Algae (Synechococcus cedrorum, Arthrospira platensis) in Natural Sea Water, Indian J. Microbiol. 5, 35-38 (1965). K.

Subbrahmanyan, R., Manna, G. B., Relative Response of the Rice Plant to Blue-Green Algae and Ammonium Sulphate in bulk Trials, Curr. Sci. 35, 482-483 (1966). O.

Subrahmanyan, R., Manna, G. B., Patnalk, S., Preliminary Observations on the Interaction of Different Rice Soil Types to Inoculation of Blue-Green Algae in Relation to Rice Culture, Proc. Indian Acad. Sci. [B] 42, 171-175 (1965). O.

Subrahmanyan, R., Relwant, L. L., Manna, G. B., Observations on the Role of Blue-Green Algae on Rice Yield Compared with that of Conventional Fertilizers, Curr. Sci. 33, 485-486 (1964). O.

Subrahmanyan, R., Relwant, L. L., Manna, G. B., Role of Blue-Green Algae and Different Methods of Partial Soil Sterilization on Rice Yield, Proc. Indian Acad. Sci. [B] 40, 293-297 (1964). O.

Subrahmanyan, R., Relwani, L. L., Manna, G. B., Fevtility Build up of Rice Field Soils by BlueGreen Algae, Proc. Indian Acad. Sci. [B] 42, 252-271 (1965). O.

Subrahmanyan, R., Relwani, L. L., Manna, G. B., Nitrogen Envichment of Rice Soils by Blue-

Green Algae and its Effect on the Yield of Paddy, Proc. Nat. Acad. Sci. India [A] 35, 382-386 (1965). $O$.

Subrahmanyan, R., Sahay, M. N., Observations on Nitrogen Fization and Organic Matter Produced by Anabaena circinalis Rabh. and their Significance in Rice Culture, Proc. Indian Acad. Sci. [B] 41, 164-169 (1965). PN.

Susor, W. A., Krogmann, D. W., Hill Activity in Cell-Free Preparations of a Bluc-Green Alga, Biochim. biophys. Acta 88, 11-19 (1964). B.

TAYLOR, F. J. R., Phytoplankton of the South Western Indian Ocean, Nova Hedwigia 12, 433-476 (1966). O, S.

Thesen der Konferenz "Sovvemennoe sostojanie i perspektivy izučenija počvennych vodoroslej SSSR" [Derzeitiger Zustand und Erforschungsperspektiven der Bodenalgen der UdSSR], Kirov, ca. 60 pp. (1966), russisch. O, P, S.

Trscher, R. G., Pure Culture of Anabaena flos-aquae A-37, Nature 205, 419-420 (1965). K.

Tretjakova, A. N., Sravnitelnoe issledovanie azotfiksirujušcich sine-zelenych vodoroslej, vydèlenych iz raznych poč SSSR. [Vergleichsstudien an stickstoffixierenden Blaualgen, isoliert aus verschiedenen Böden dev UdSSR], Mikrobiologiya 34, 491-496 (1965), russisch. P.

Tritjakova, A. N., Effect of Light on Growth and Nitrogen Fixation by Soil Blue-Green Algae, Mikrobiologiya 35, 721 (1966). P.

TschermaK-WOEss, E., UUber auffallend ungleiche und kleine Gametenzellen und die Frage einer selektiven Paarung bei Gomphonema olivaceum, Nova Hedwigia 12, 367-372 (1966). M, C.

Umezaкi, I., On the Classification of the Blue-Green Algae (Cyanophyta), Bull. Jap. Soc. Phycol. 41, 149-163 (1966). S.

VANCE, B. D., Sensitivity of Microcystis aeruginosa and Other Blue-Green Algae and Associated Bacteria to Selected Antibiotics, J. Phyc. 2, 125-128 (1966). P. 
Varma, A. K., Mitra, A. K., Venkataraman, G. S., Role of Aulosiva fertilissima in the Nitrogen Economy of the Soil, Phykos 3, 29-32 (1964). O.

Venkataraman, G. S., Thermal Resistance and Viability of Microalgae, Phykos 3, $26-28$ (1964). P. Venkataraman, G. S., Algalization, Phykos 6, 164-174 (1966). V.

Vennesland, B., Turkingron, E. O., The Relationship of the Hill Reaction to Photosynthesis: Studies with Fluoride-Poisoned Blue-Green Algae, Arch. Biochem. Biophys. 116, 153-161 (1966). P.

Voropaeva, O.G., O fiksacii azota vozducha nekotorymi vidami sine-zelenych vodoroslej, vydělennych $s$ risovych polej srednèj Asii. [Über die Fixation des Luftstickstofjes durch einige Blaualgenavten,, isoliert aus Reisfeldern in Zentral-Asien], Uzbekskij biol. Z. 10, $52-55$ (1966), russisch. P.

VRedenberg, W. J., Duysens, L. N. M., Light-Induced Changes in Absovbancy and Finovescence of Chlorophyllous Pigments Associaled with the Pigment Systems 1 and 2 in Blue-Green Algae, Biochim. biophys. Acta 94, 355-370 (1965). B.

Walsby, A. E., Biochemical Studies on the Extracellular Polypeptides of Anabaena cylindrica Lemm., Brit. Phyc. Bull. 2(6), 514-515 (1965). B.

Watanabe, A., Hattori, A. (Editors), Cultures and Collections of Algae, Proceedings of the U.S.-Japan Conference held at Hakone, September 12-15, 1966. Japan. Soc. of Plant Physiologists, viii + 100 pp. K. (inkl. Cyanophyceae).

Webster, D. A., HACKeTt, D. P., The Purification and Properties of Cytochrome "o" from Vitreoscilla, J. biol. Chemistry 241, 3308 (1.966). B.

Welsh, H., An Introduction to the Blue-Green Algae with a Dichotomous Key to all the Genera, Newsletter Limnological Soc. Southern Africa 7(2), 25-53 (1964). S.

Whiтton, B. A., Algae in St. James Park Lake, London Naturalist 45, 26-28 (1966). S.

Wiedeman, V. E., Chemical Analyses and Algai Composition in a Waste-Stabilization Pond System, Southwestern Naturalist 10, 188-210 (1965). O.

Willek, T., Phytoplankton from Swedish Lakes. I. Lake Magelungen, 1960-1963, Oikos 17, 231-249 (1966). O.

Wilson, A. T., Escape of Algae from Frozen Lakes and Ponds, Ecology 46, 376 (1965). 0.

Wolk, C. P., Control of Sporulation in a Blue-Green Alga, Devl. Biol. 12, 15-35 (1965). P.

YonedA, Y., Cyanophyta, aus: An Outline of Modern Biology, Bd. 5 (Nakayama Shoten, Tokyo 1966), p. 73-101, pl. IV, V.

ZAFAR, A. R., Limnology of the Husain Sagar Lake, Hyderabad, India, Phykos 5, 115-126 (1966). O.

Zaneveld, J. S., The Marine Algae of the American Coast between Cape May, N.J. and Cape Hatteras, N.C. I. The Cyanophyta, Bot. Marina 9, 101-128 (1966). S.

Z Hevner, V. D., Gusev, M. V., Shestakov, S. V., Changes in the Pigment Composition and Content of Blue-Green Algae as a Factor of the Spectral Composition of Light and Degree of Illumination, Mikrobiologiya 34(2), 209-215 (1965), russisch. P.

\section{Blaualgenliteratur aus den Jahren 1967 und 1968}

Agarkar, D. S., Two New Records of Myxophyceae from Gwalior (m.p.) Scytonema chiastum, Microchaete violacea $f$. hyalinus $f$. nov. . Curr. Sci. (India) 36, 189-190 (1967). S, O.

Анмад, M. R., Observations on the Effect of Feeding Labeo rohita (Ham.) with Microcystis aeruginosa Kiitz., Hydrobiologia 29, 388-392 (1967). V.

Ahmadjian, V., A Guide to the Algae Occurving as Lichen Symbionts: Isolation, Cullure, Cultural Physiology, and Identification, Phycologia 6, 127-160 (1967). S, K, P.

Akiyama, M., Nishigami, K., Soil Algal Vegetation Found in the Newly Reclaimed Region of the Brackish Lake Nakano-Umi, Jap. J. Ecol. 17, 118-121 (1967), japanisch, mit englischer Zusammenfassung. $\mathrm{O}, \mathrm{S}$.

Alfimov, N. N., Makerova, I. V., Fadeyeva, O. N., A Contribution to the Ecological and Chemical Chavacterization of Some Species of Blue-Green Algae, Bot. Z. 53, 106-109 (1968). O.

Allen, G. F., Franke, H., Hrrayama, O., Identification of a Plastoquinone and Two Naphthoquinones in Anacystis nidulans by NMR and Mass Spectroscopy. Biochem. biophys. Research Comm. 26, 562-568 (1967). B.

Allen, M. A., Studies on the Properties of Some Blue-Green Algae, Diss, Abstr. 28 (1B): 269B (1967). M, P (Anacystis, Coccochloris). 
Almestrand, A., Taxonomische Studien ïber Cyanophyceen aus Oxydationsteichen, Schweiz. Z. Hydrol. 29, 199-210 (1967). O, S.

Almodovar, L. R., Pagan, F. A., Notes on the Algae of Barbados, Nova Hedwigia 13, 111-115 (1967). O (inkl. Cyanophyceae).

Amma, P. A., Aiyer, R. S., Subramoney, N., Occurrence of Blue-Green Algae in the Acid Soils of Keraia, Agr. Res. J. (Kerala) 4, 140-143 (1967). O.

ANAGNostidis, K., RatHSACK-KüNZENBACH, R., Isocystis pallida-Blanalge oder hefeartiger Pilz? Schweiz. Z. Hydrol. 29, 191-198 (1967). S.

Anonymus, A New Type of Food Algae, Inst. franc. du pétrole, réf. 14237 A: 8 pp. 1967. K, P (Spirulina).

Anonymus, Controlling Algae in Water, BR 1092 151, Great Lakes Biochemical Co. 1967. O (ink1. Cyanophyceae).

Antia, N. J., Chorney, V., Nature of the Aldolase Activity in a Unicellular Red Alga (Porphyridium cruentum), Nature (London) 214 (5092), 1028-1029 (1967). B (inkl. Cyanophyceae).

Aplin, T. E. H., Water Blooms, J. Agr. West Austr. 8, 472-474 (1967). O (Anacystis).

ARChibald, C. G. M., Some New and Interesting Cyanophytes from the Kowie River System in the Eastern Cape Province (South Africa). I. Nova Hedwigia 12, 529-538 (1967). S.

Archibald, C. G. M., New and Interesting Cyanophytes from the Kowie River System in the Eastern Cape Province (South Africa). II., Nova Hedwigia 13, 389-395 (1967). S.

Aschner, B., Laventer, C., Chorin-Kirsch, I., Off Flavour in Carp from Ponds in the Coastal Plain and the Galil, Bamidgeh 19, 23-25 (1967). O.

Ascione, R., The Use of Enzymes from Thermophilic Organisms to Investigate the Biological Role of Macro Molecular Structure in Soluble RNA, Diss. Abstr. 28 (4B), 1388 B - 1389 B (1967). B (Cyanidium).

Awasthr, P., Behaviour of Catalase in Some Members of Chlorophyceae and Cyanophyceae, Rev. Algol. 8, 307-311 (1967). B (Oscillatoria, Phormidium).

BaAlen, C., van, Further Observations on Growth of Single Cells of Coccoid Blue-Green Algae, J. Phycol. 3, 154-157 (1967). P.

Backhaus, D., Notizen zur Morphologie, Systematik und Öhologie einiger Chamaesiphon-Avten aus Fliessgewässern, Schweiz. Z. Hydrol. 29, 211-225 (1967). M, O, S.

BackHaus, D., Okologische Untersuchungen an den Aufwuchsalgen der obersten Donau und ihrer Quellflïsse. I., Arch. Hydrobiol., suppl. 30, 364-399 (1967). O (inkl. Cyanophyceae).

BAKER, A. N., Algae from Lake Miers, a Solar-Heated Antarctic Lake, N. Z. J. Bot. 5, 453-468 (1967). O (inkl. Cyanophyceae).

Batterton, J. C., Banten, C., van, Characteristics of Phosphate Uptake and Phosphate Deficient of Anacystis nidulans, J. Phycol. 3 (suppl.), p. 8 (1967). P.

Bergeron, J. A., Olson, J. M., Low-Temperature Fluorescence Emission and Exitations Spectra for Anacystis nidulans, Biochim. biophys. Acta 131, 401-404 (1967). P.

Berns, D. S., Immunochemistry of Biliproteins, Plant Physiol. 42, 1569-1586 (1967). B.

Biggins, J., Preparation of Metabolically Active Protoplasts from the Blue-Green Alga, Phormidium luridum, Plant Physiol. 42, 1442-1446 (1967). B.

Biggins, I., Photosynthetic Reactions by Lysed Protoplasts and Particle Preparations from the Blue-Green Alga, Phormidium luridum, Plant Physiol. 42, 1447-1456 (1967). B.

BoHr, R., Zbiorowiska glonow perifitonowych jezior Polski polnocnej.-.-Communities of the Periphyton Algae of Some Lakes in North Poland, Zesz. nauk. Uniw. M. Kopernika (Torun), mat.-przyr. 17, 33-104 (1967), polnisch mit englischer Zusammenfassung. O (inkl. Cyanophyceae).

BoHr, R., ZAwiśLAK, W., Production of Periphyton in the Jeziorak Lake, Zesz. nauk. Uniw. M. Kopernika (Toruí), mat.-przyr. 18, 3-10 (1967). O (inkl. Cyanophyceae).

Boly ŠEv, N. N., Ob učastii vodoroslej v obrazovanii pozv. (Über den Anteil der Algen an der Bodenbildung), Sovr. sostojanie i perspektivy izučenija počv. vodoroslej v SSSR (Kirov) 20, 23-31 (1967). O, PN.

Bose, S., Crespi, H. L., Blake, M. I., Katz, J. J., Comparative Studies of Photosynthetic Processes in Ordinary and Full Deuterated Algae (Chlovella vulgaris, Scenedesmus obliquus and Synechococcus lividus), Plant Cell. Physiol. 8, 545-555 (1967). P.

Bostwick, C. D., Brown, L. R., Tischer, R. G., Some Observations on the Sodium and Potassium Interactions in the Blue-Green Alga Anabaena flos-aquae A-37, Physiol. Plant. 21,466-469 (1968). P. 
Bourdu, R., LEForT, M., Structure fine, observée en cryodecapage, des lamelles photosynthétiques des Cyanophycées endosymbiotiques: Glaucocystis nostochinearum Itzigs. et Cyanophora paradoxa Korschikoft, C. R. Acad. Sci. Paris 265, 37-40 (1967). Cu.

Bringmann, G., In vitro-«Wasserblitten»-Test mit Microcystis aeruginosa, Ges. - Ing. 88, 256-260 (1967). O, P,

Brock, T. D., Life at High Temperatures. Evolutionary, Ecological, and Biochemical Significance of Organisms Living in Hot Springs is Discussed, Science 158, 1012-1019 (1967). O, B.

BRock, T. D., Micro-Organisms Adapted to High Temperatures, Nature 214, (5091) 882-885 (1967). $\mathrm{O}, \mathrm{P}$.

Brock, T. D., Vertical Zonation in Hot Springs Algal Mats, Phycologia 7 (in press) 1968. O, S.

BRock, T. D., Brock, M. L., The Measurement of Chlorophyll, Primary Productivity, Photophosphorylation and Macromolecules in Benthic Algal Mats, Limnol. Oceanogr. 12, 600-605 (1967). P, B.

Brock, T. D., Brock, M. L., Measurement of Steady-State Growth Rates of a Thermophilic Alga Directly in Nature, J. Bacteriol. 95, 811-815 (1968). O.

Bucka, H., Kyselowa, K., Plankton wybranych stawow karpiowych w Golvszu $i$ Landeku (The Plankton of Selected Carp Ponds at Golysz and Landeh), Acta Hydrobiologica 9, 339-380 (1967), polnisch. O (inkl. Cyanophyceae).

Bট̈chel, K. H., Röchling, H., Baedelt, H., Gerhardt, B., Trebst, A., Hemmung dev Photosynthese in Anacystis durch Alkylbenzimidazol, Z. Naturforsch. 22B, 535-537 (1967). B.

Burnham, J. C., Hageage, G. J., Jr., Adenosine Phosphate Hydrolases in Cell Fractions of Vitreoscilla, J. Bacteriol. 93, 191-198 (1967). B.

Burns, C. W., The Feeding Behaviour of Daphnia Under Natural Conditions, Diss. Abstr. (4B) 28, 1723 B-1724 B (1967). V (inkl. Cyanophyceae).

Buzzel, J. C., Jr., SAwyer, C. N., Removal of Algal Nutrients trom Raw Wastewater with Lime, J. Water Poll. Contr. Fed. 39, 16-24 (1967). O.

Capesius, I., Richter, G., Enzyme der Polynucleotid-Synthese in pflanzlichen Organismen. I. Isolierung, Reinigung und Charakterisierung der Polynucleotid-Phosphorylase aus der Blaualge Anacystis nidulans, Z. Naturforsch. 22b, 204-215 (1967). B.

Capesius, I., Richter, G., Enzyme der Polynucleotid-Synthese in pflanzlichen Organismen. II. Isolierung, Reinigung und Charakterisierung der RNA-Polymerase aus der Blanalge Anacystis nidulans, Z. Naturforsch. 22b, 876-885 (1967). B.

Carr, N. G., Exell, G., Flynn, V., Hallaway, M., Talukdar, S., Minor Quinones of Some Myxophyceae, Arch. Biochem. Biophys. 120, 503-507 (1967). B.

Castenholz, R. W., Aggregation in a Thermophilic Oscillatoria, Nature (London) 215 (5107), 1285-1286 (1967). P.

Cheniae, G. M., Martin, I. F., Photorelactivation of Manganese Catalyst in Photosynthetic Oxygen Evolution (Anacystis nidulans), Biochem. Biophys. Res. Comm. 28, 89-95 (1967). P.

Cholnoky-Pfannuuche, K., Beiträge zur Kenntnis der Zytologie der Cyanophyten, Arch. Hydrobiol. 63, 243-249 (1967). C.

Cholnoky-Pfannkuche, K., Z zei neue Lyngbya-Arten aus Süd-Afrika, Nova Hedwigia 14, 13-16 (1967). S.

Cholnoky-Prannkuche, K., Permeabilitätsversuche mit Harnstoff, Revista de Biologia 6, 35-48 (1967). P (Lyngbya).

Clement, G., Giddey, C., Menzr, R., Amino Acid Composition and Nutritive Value of the Alga Spirulina maxima, J. Sci. Fd. Agric. 18, 497-501 (1967). P.

Cole, W. J., Chapman, D. J., Sregelman, H. W., The Structure of Phycocyanobilin, J. Amer. chem. Soc. $89(14), 3643$ (1967). B.

Collier, A., Fatty Acids in Certain Plankton Organisms, Proc. of the Conference on Estuaries, 31 March-3 April 1964, Jokoll Islands, D. C. Amer. Ass. Advanc. Sci. Publ. 83, 353-360 (1967). P (inkl. Cyanophyceae).

Compère, P., Algues du Sahara et de la végion du lac Tchad, Bull. Jard. bot. nat. Belg. 37, 109-288 (1967). O, S (inkl. Cyanophyceae).

Cox, R. M., A Re-Examination of the Problem of Photochemical Nitrogen Reduction by Blue-Green Algae, Arch. Mikrobiol. 56, 193-201 (1967). B.

Cox, R. M., FAY, P., Nitrogen Fixation and Pyruvate Metabolism in Cell-Free Preparations of Anabaena cylindrica, Arch. Mikrobiol. 58, 357-365 (1967). B, PN. 
Craig, I. W., Carr, N. G., Ribosomes from the Blwe-Green Alga Anabaena variabilis, Biochem. J. 103, $64 \mathrm{P}(1967)$. B.

Crespi, H. L., Boucher, L. J., Norman, G. D., Katz, J. J., Dougherty, R. C., Structure of Phycocyanobilin, J. Amer. chem. Soc. 89(14), 3642 (1967). B.

Danilevskaja, I. P., Tkačenko, M. S., Ivanov, A. I., Braginskij, L. P., Opyt primenenija koaglujantov dlja osaždenija gustych mass sine-zelenych vodoroslej. (Der Einfluss von Koagulationsmitteln aut die Sedimentation dichter Blaualgenmassen), Gidrobiolog. Z. 3, 68-70 (1967). P, O.

Darley, J., On Some Results of the Laboratory Culture of Two Species of Calothrix (MyxophyceaeRivulariaceae), C. R. Hébd. Séances Acad. Sci. [sér. D, nat.], (Paris) 264, 1013-1015 (1967). K.

DaRzNIEK, J. O., Azotfiksinujuščaja vodorosl, Calothrix elenkinii Kossinsk. iz rybovodnogo pruda. (Calothrix elenkinii Kossinsk., eine stickstoffbindende Alge aus einem Fischteich), Izv. AN Turkm. SSR, ser. biol. n. 1967 (2), 57-60 (1967). PN.

Davies, H. W., Jr., Ecology and Seasonal Variation of the Psammon Flova of a Sandy Beach Transect, Diss. Abstr. 28 [1B], 62 B-63 B (1967). O.

Davis, E. M., Wтьсомв, M. J., Condensed Phosphate degradation and Assimilation by Selected Blue-Green Algae, Water Res. 2, 311-324 (1968). P.

Derbyshire, E., Whitton, B. A., A Disc Electrophoretic Study of Proteins of Blue-Green Algae, Phytochem. 7, 1355-1360 (1968). B.

Dillard, G. E., The Fresh-Water Algae of South Carolina. I. Previous Work and Recent Additions, J. Elisha Mitchell Sci. Soc. 83, 128-131 (1967). S, O (inkl. Cyanophyceae).

DolGICH, J. R., Vlijanie sine-zelenych vodoroslej visovogo polja na gazovyj vełzim vody i okislitelnovosstanovitelnye processy pocvy. (Der Einfluss der Blaualgen eines Reisfeldes auf den Gashaushalt des Wassers und die Oxydationsprozesse des Bodens), Sovr. sostojani i perspektivy izucenija počv. vodoroslej v SSSR (Kirov) 20, 281-286 (1967). O.

Dor, I., Algues des sources thermales de Tibériade, Bull. Sea Fish. Res. Stat. (Haifa) 48, 3-29 (1967). O.

Dorogostaiskaya, E. V., Novičkova-Ivanova, L. N., Ob izmenenii algoflovy tundrovych počv rezultate ich osvoeniya (Changes in the Algae of Tundra Soils, Resulting from their Reclamation), Bot. Z. 52, 461-468 (1967). O.

Drew, E. A., Smrtr, D. C., Studies in the Physiology of Lichens. VII. The Physiology of the Nostoc Symbiont of Peltigera polydactyla Compared with Cultured and Free-Living Forms, New Phytol. 66, 379-388 (1967). O.

Drew, E. A., Smith, D. C., Studies in the Physiology of Lichens. VIII. Movement of Glucose from Alga to Fungus During Photosynthesis in the Thallus of Peltigera polydactyla, New Phytol. 66, 389-400 (1967). O (Nostoc).

Dugdale, W. A., Inorganic Nitrogen Metabolism and Phytoplankton Primary Productivity in a Subarctic Lake, Diss. Abstr. 28(3B), 800 B-801 B (1967). O, PN.

Echlin, P., The Biology of Glancocystis nostochinearum. I. The Morphology and Fine Structure, Brit. phycol. Bull. 3, 225-239 (1967). M, Cu.

Echlin, P., The Use of the Scanning Reflection Electron Microscope in the Study of the Algae (Abstract), Brit. phycol. Bull. 3, 413 (1967). Cu (inkl. Cyanophyceae).

Edelman, M., Swinton, D., Schiff, J. A., Epstein, H. T., Zeldin, B., Deoxyribonucleic Acid of the Blue-Green Algae (Cyanophyta), Bact. Reviews 31, 315-331 (1967). B.

Edwards, M. R., Holt, S. C., Berns, D., Comparative Study of Synechococcus lividus by Thin Sectioning, Negative Staining and Freeze-Etching Techniques, J. Cell Biol. 35(2), pt. 2, 36a (1967). $\mathrm{C}, \mathrm{Cu}$.

Evans, J. H., The Coulter Counter and its Use in Determining the Concentration of Natural Populations of Fresh Water Phytoplankton (Abstract), Brit. phycol. Bull. 3, 411 (1967). V (Microcystis).

Fagerstrom, J. A., Development, Flotation and Transportation of Mud Crusts-Neglected Factors in Sedimentology, J. Sediment. Petrol 37, 73-79 (1967). O.

FAY, P., Cox, R. M., Oxygen Inhibition of Nitrogen Fixation in Cell-Free Preparations of BheGreen Algae, Biochim. biophys. Acta 143, 562-569 (1967). PN.

Feortistova, O. I., Opredelenie optimalnych uslovij dliny dnja $i$ intensivnosti sveta dlja rosta $i$ nakoplenija azota azotfiksirujušcimi sinezelenymi vodorosljami. (Untersuchungen über die optimale Tageslänge und Beleuchtungsintensität für das Wachstum und die Stickstoffspeicherung stickstoffbindender Blaualgen), Biologiceskij azot v s/ch, p. 317-324 (1967). O, PN. 
FEOKTISTOVA, O. I., Vlijanie fahtorov vnešnej sredy na azotfiksaciju sine-zelenych vodoroslej. (Einfluss der Aussenbedingungen auf die Stickstofibindung der Blaualgen), Sovr. sostojanie i perspektivy izučenija počv. vodoroslej v SSSR (Kirov) 20, 155-166 (1967). PN.

Findenegg, I., Die Bedeutung des Austausches für die Entwicklung des Phytoplanktons in den Ostalpenseen, Schweiz. Z. Hydrol. 29 (1), 125-144 (1967). O.

FoGG, G. E., Some Problems Presented by the Blue-Green Algae, J. Queckett microsc. Club 30 , 261-267 (1967). P.

Fork, D. C., AMEsz, J., Light-Induced Shifts in the Absorption Spectrum of Carotenoids in Red, Brown, and Yellow-Green Algae and in a Barley Mutant, Carnegie Inst.'Wash. Yearb. 1966/1967. $P$.

Fork, D. C., Amesz, J., Transfer of Energy Between Reaction Centres of Photosystems in Algae, Carnegie Inst. Wash. Yearb. 66, 155-160 (1966/1967). P (inkl. Cyanophyceae).

Fredrick, J. F., Multiple Forms of Polygincoside-Branching Enzyme in the Algae, Physiol. Plant. 27, 176-182 (1968). B, P (inkl. Cyanophyceae).

Frederickson, A. G., Ramakrishana, D., Tsuchiya, H. M., Statistics and Dynamics of Procaryotic Cell Populations, Math. biol. Sci. 1, 327-374 (1967). K, O.

Fujita, Y., Myers, J., Kinetic Analysis of Light-Induced Cytochrome c Redox Reactions in Anabaena Lamellar Fragmenis, Arch. Biochem. Biophys. 119, 8-15 (1967). B.

Fulco, L., Karfunkel, P., Aaronson, S., Effect of Lysozyme (Muramidase) on Marine and Freshwater Blue-Green Algae, J. Phycol. (N. Y.) 3, 51--52 (1967). P.

Funk, W. H., Phytoplankton Productivity of a Newly Developed Reservoir, Diss. Abstr. [81B] 27, 2916 B (1967). O.

GÄсHTER, R., Phosphorhaushalt und planktische Primärproduktion im Vierwaldstättersee (Hovwer Bucht), Schweiz. Z. Hydrol. 30, 1-66 (1968). O (inkl. Cyanophyceae).

Galling, G., Stimulierung des Aminosäure-Einbaus durch verschiedene Nukleinsäure-Präparationen in zellfreien Systemen aus Chlorella und Anacystis, Z. Naturforsch. [B] 22, 687-688 (1967). B.

Gamulin-Brida, H., Giaccone, G., Golubić, S., Contribution aux études des biocoenoses subtidales, Helgoländer wiss. Meeresunters. 15, 429-444 (1967). O (inkl. Cyanophyceae).

GapočkA, L. D., Issledovanie vlijanija razliznych sacharov na rost sinezelenoj vodorosli Anacystis nidulans. (Untersuchungen über den Einfluss verschiedener Glyzide aut das Wachstum der Blaualge Anacystis nidulans), Bjull. mosk. Ob-va Ispyt. Prir., otd. biol. 22, 150-151 (1967). P.

GEITLER, L., Entwicklungsgeschichtliche und systematische Untersuchungen an einigen Cyanophyceen, Nova Hedwigia 13, 403-422 (1967). S.

Gertler, L., I socystis pallida - keine Cyanophyceae, Schweiz. Z. Hydrol. 30, 186-187 (1968). S.

GerhardT, B, Photosynthetische Frahtionen in zelltreien Systemen aus Anacystis, Ber. dt. bot. Ges. $78,400-404$ (1967). B.

GERHARDT, B., WIESSNER, W., On the Light-Dependent Reactivation of Photosynthetic Activity by Manganese, Biochem. Biophys. Res. Commun. 28, 958-964 (1967). B (Anacystis).

Gerlofr, G. C., The Comparative Boron Nutrition of Several Green and Blue-Green Algae, Physiol. Plant. 21, 369-377 (1968). P.

Goedfeer, J. C., Variations in the Absorption Spectrum and of Fluovescence in the Course of Turning Green and of Aging in Plastids (Phaseolus multiflorus), The chloroplast: Growth and aging (Paris), p. 77-85 (1967). P (Anacystis).

Goldstein, D. A., Bendet, I. J., Physical Properties of the DNA from the Blue-Green Algal Virus LPP-7, Virology 32, 614-618 (1967). B.

Goldstein, D. A., Bendet, I. J., Lauffer, M. A., Some Biological and Physicochemical Properties of Blue-Green Algal Virus LPP-1, Virology 32, 601-613 (1967). B.

Golle RBACH, M. M., Voprosy sistematiki vodoroslej potvenno-algologiteskich problem. (Die Fragen der Algensystematik in der Bodenalgenproblematik), Sovr. sostojanie i perspektivy izucenija počv, vodoroslej v SSSR (Kirov) 20, 32-40 (1967). S.

Golubić, S., Die Algenvegetation an Sandsteinfelsen Ost-Venezuelas (Cumaná), Int. Revue ges. Hydrobiol. 52, 693-699 (1967). O (inkl. Cyanophyceae).

Golubić, S., Die litorale Algenvegetation des Titisees, Arch. Hydrobiol., suppl. 33, 172-205 (1967). O (inkl. Cyanophyceae). 
Golubić, S., Zwei wichtige Merkmale zur Abgrenzung der Blaualgengattungen, Schweiz. Z. Hydrol. 29, 176-184 (1967). S.

Golubic, S., Uber den Autbau des Taxons bei den Cyanophyten anhand der Beispiele Tolypothrix, Oscillatoria und Gloeocapsa, Verh. int. Verein. Limnol. 16(3), 1577-1581 (1967). S.

Golubic, S., Algenvegetation der Felsen, in: Die Binnengewässer, Bd. 23 (Stuttgart 1967), O, S., inkl. Cyanophyceae.

Golubic, S., KanN, E., Zur Klärung der taxonomischen Beziehungen zwischen Tolypothrix distorta Kïtzing und T. penicillata Thuret (Cyanophyta), Schweiz. Z. Hydrol, 29, 145-160 (1967). S.

Gorbunova, N. P., Kratkij oðerk istorii izuと̌nija vodoroslej v Moshovskom Universitete za poslednie 50 let. (Kurze Ubersicht über die Algenforschung an der Moskauer Universität während der letzten 50 Jahre), Vestnik Mosk. Univers., ser. 6 (biol. počv.), (5), 56-62 (1967). V.

Gorbunova, N. P., O massovom razvitiji Sphaeronostoc pruniforme (Ag.) Elenk. v okvesinostjach Jaroslavlja. (Ưber die Massenentwicklung von Sphaeronostoc pruniforme (Ag.) Elenk. in der Umgebung von Jaroslavl), Bjull. mosk. Ob-va Ispyt. Prir., otd. biol., 72, 89-96 (1967). O.

Gorbunova, N. P., Razmnozenie Sphaeronostoc pruniforme (Ag.) Elenk. $i$ nekotorye spornye voprosy taksonomii sine-zelenych vodoroslej. (Propagation of Sphaeronostoc pruniforme and Some Disputable Problems of the Taxonomy of Blue-Green Algae), Bot. 2. 52, 344-347 (1967), russisch, mit englischer Zusammenfassung. S.

GrorJunova, S. V., ORLEANSKIJ, V. K., Izučenie rosta i razvitija sine-zelenoj vodorosli Gloeotrichia natans $f$. bucharica Kissel. (Wachstum und Entwicklung der Blaualge Gloeotrichia natans $f$. bucharica Kissel), Sovr. sostojanie i perspektivy izučenija počv. vodoroslej v SSSR (Kirov) 20, 192-201 (1967). O, S.

Gorjunova, O. V., ORLEANSKiJ, V. K., Sovremennyje metody primenenija azotfiksirujušich sinezelenych vodoroslej dlja povysenija plodorodija risovych polej. (Moderne Methoden der Benuitzung von stickstoffbindenden Blaualgen zur Evtragserhöhung der Reisfelder), Biologiceskij azot $i$ ego rol v zemedelii, Izd. "Nauka», M, 309-316 (1967). PN.

GRUžEvo, A. S., O fiksacii azota sine-zelenymi vodorosljami v potve. (Ưber die Stickstoffbindung durch Blaualgen im Boden), Sovr. sostojanie i perspektivy izučenija počv. vodoroslej v SSSR (Kirov) 20, 262-265 (1967). PN.

Gusev, M. V., Chromatičeskie charakteristiki Cyanophyta. (Chromatische Merkmale der Cyanophyceen), Sovr. sostojanie i perspektivy izučenija počv. vodoroslej v SSSR (Kirov) 20, 151-154 (1967). P.

Gusev, M. V., Ževner, V. D., ک̌estakov, S. V., Chromatičeskie izmenenija u sine-zelenych vodoroslej. (Chromatische Veränderungen der Blaualgen), Naučn. Dokl. vysš. Školy, Biol, n., 1 , 154-155 (1967). P.

Hall, W. T., Claus, G., Ultrastructural Studies on the Cyanelles of Glaucocystis nostochinearum Itzigsohn, J. Phycol. 3, 37-51 (1967). CU.

de Halperin, D. R., Marine Cyanophyceae from Puerto Deseado (Santa Cruz Province, Argentine). II., Darwiniana (Buenos Aires) 14, 273-354 (1967). O.

Hammer, L., Die Primärproduktion im Golf von Caraico (Ost-Venezuela), Int. Revue ges. Hydrobiol. 52, 757-768 (1967). O.

Hanak, M., Glony kilku stawkow okolic Krakowa. (Algae of Some Small Ponds Near Cracow), Acta Hydrobiol. 9, 433-447 (1967), polnisch, O, S (inkl. Cyanophyceae).

Harvey, R. S., Patrick, R., Concentration of $C s^{137}, Z n^{65}$ and $S r^{85}$ by Fresh-Water Algae, Biotechnol. Bioeng. 9, 449-456 (1967). P (inkl. filamentous Cyanophyceae).

Hattori, A., Myers, J., Reduction of Nitrate and Nitrite by Subcellular Preparations of Anabaena cylindrica. II. Reduction of Nitrate to Nitrite, Plant Cell Physiol. 8, 327-337 (1967). PN.

Healey, J. S., Poisonous Algae, Agr. Gaz. N. S. W. 78, 666-667 (1967). Pт (Anacystis).

HeIM, K., ZILLIG, W., Reinigung und Eigenschaften der DNA-abhängigen RNA-Polymerase aus Anacystis nidulans, Hoppe-Seylers Z. Physiol. Chem. 348, 902-912 (1967). B.

Hertzberg, S., Jensen, S. L., The Carotenoids of Blue-Green Algae. III. A Comparative Study of Mutatochrome and Flavicin, Phytochem. 6, 1119-1126 (1967). B.

Hickel, W., Investigations on the Phytoplankton Bloom in the Western Baltic, Helgoländer wiss. Meeresunters. 16, 3-66 (1967). O.

Hirayama, O., Lipids and Lipoprotein Complex in Photosynthetic Tissues. II. Pigments and Lipids in a Blue-Green Alga, Anacystis nidulans, J. Biochem. 61, 179 (1967). B. 
Hirayama, O., Lipids and Lipoprotein Complex in Photosynthetic Tissues. III. Characterization of Lamellar Fractions Isolated from a Blue-Green Alga Anacystis nidulans, Agr. biol. Chem. 31, 947-952 (1967). B.

Hirose, H., Akayama, M., A Review of Aerial and Soil Algae. III., Bull. Jap. Soc. Phycol. 15, 47-50 (1967). O.

Hoare, D. S., Hoare, S. I., Moore, R. B., The Photoassimilation of Organic Compounds by Autotropic Blue-Green Algae, J. gen. Microbiol. 49, 351-370 (1967). P (Anacystis, Anabaena, Nostoc).

Hoek, C. van DEN, Donze, M., Algal Phytogeography of the European Atlantic Coasts, Blumea 15, 63-89 (1967). O (inkl. Rivularia).

Holm-Hansen, O., Factors Affecting the Viability of Lyophilized Algae, Cryobiology 4, 17-23 (1967). P (Gloeocapsa, Nostoc).

Holohan, P. D., Moore, R. B., Chemical Changes Accompanying Photomorphogenesis of a BlueGreen Alga, J. Phycol. 3 (suppl.), 8 (1967). P.

Holton, R. W., Myers, J., Water-Soluble Cytochvomes from a Blue-Green Alga. I. Extraction, Purification and Spectral Properties of Cytochromes $C(549,552$ and 554, Anacystis nidulans), Biochim. biophys. Acta 731, 362-374 (1967). B.

Holton, R. W., Myers, J., Water-Soluble Cytochromes from a Blue-Green Alga. II. Physicochemical Properties and Quantitative Relationships of Cytochromes $C(549,552$ and 554, Anacystis nidulans), Biochim. biophys. Acta 131, 375-384 (1967). B.

Hood, W., Carr, N. G., A Single Glyceraldehyde-3-Phosphate Dehydrogenase Active with $N A D$ and NADP in Anabaena variabilis, Biochim. biophys. Acta 146, 309-311 (1967). B.

HoRtoBAGyi, T., Magyavország halastavainak mikrovegetacioja IV. (Micro-Vegetation in the FishPonds of Hungary. IV.), Hidrol. Közlöny 8, 337-348 (1967), ungarisch, mit englischer Zusammenfassung. O (ink1. Cyanophyceae).

Hortobagyi, T., Vigassy, J., Micro-Organisms in the Water Circuits Exposed to Radiation of the Nuclear Reactor, Budapest-Csillebérc, Acta biol. Acad. Sci. Hung. 18, 151-160 (1967). O (inkl. Cyanophyceae).

HülsbruCH, M., Die "Moorschnecke》 (Leptobasis goesingense Palik) im Heideweiher des Naturschutzgebietes Heiliges Meer bei Hopsten, Ber. dt. bot. Ges. 80, 367-370 (1967). S, O.

Ignatevskaja, M. A., Rarkov, N. I., Vlijanie koncentracij svedy na fiziologiju Anacystis nidulans $v$ islovijach intensivnoj kultury. (Effect of the Concentration of Nutrient Medium Salts on the Physiology of Anacystis nidulans Under Conditions of Intense Culture), Fiziologija rastenij 14, 634-643 (1967), russisch, mit englischer Zusammenfassung. P.

Jahnke, E., Die Rolle stickstoffbindender Blaualgen in Böden, Zbl. Bakteriol., Parasitenk., Infektionskrank. Hygiene (Jena) 127, 636-642 (1967). PN.

Jain, P. K., Kumar, H. D., Singh, M. K., Adaptation of the Blue-Green Alga Anabaena variabilis to Hydroxylamine, Plant Cell Physiol. 8, 347-351 (1967). P.

JEFFRRY, P. D., Equilibrium Sedimentation of the Interacting Protein C-Phycocyanin (Plectonema calothricoides) in a Density Gradient, Biopolymers 5, $791-795$ (1967). B.

Jenkins, D., Medsker, L. L., Thomas, J. F., Odorous Compounds in Natural Waters. Some Sulfur Compounds Associated with Blue-Green Algae, Environ. sci. Technol. 1, 731-735 (1967). O, P.

Jónasson, P. M., Kristiansen, J., Primary and Secondary Production in Lake Esrom. Growth of Chironomus anthracinus in Relation to Seasonal Cycles of Phytoplankton and Dissolved Oxygen, Int. Revue ges. Hydrobiol. 52, 163-217 (1967). O (inkl. Cyanophyceae).

JURGENSEN, M. F., The Enumevation and Identification of Nonsymbiotic Nitrogen Fixing Microovganisms Found in Acid Forest and Nursery Soils, Diss. Abstr. 27 [12B], 4212 B (1967). PN.

Kalininskaja, T. A., Melody vydelenija $i$ kultivirovanija azotfiksirujušcich mikrobnych associacij. (Methods for Isolation and Study of Nitrogen Fixing Microbial Associations), Mikrobiologija 36, 345-349 (1967), russisch, mit englischer Zusammenfassung. PN.

Kaye, A. M., Salomon, R., Fridlender, B., Base Composition and Presence of Methylated Bases in DNA from a Blue-Green Alga Plectonema boryanum, J. molec. Biol. 24, 479-483 (1967). B.

Kobayashi, M., TaKabashi, E., Distribution of Nitrogen Fixing Microorganisms in Paddy Soils of South East Asia, Soil Sci. 104, 113-118 (1967). O, PN.

Kogan, Sy. I., On the Tropical Element in the Flora of Blue-Green Algae in the Water Bodies of the Southern Turkmenia, Bot. Z. 52, $952-959$ (1967), russisch, mit englischer Zusammenfassung. $\mathrm{S}, \mathrm{O}$. 
KomÁREK, J., VAVRA, J., Identity of a Blue-Green Alga Marssoniella elegans with a Microsporidian Gurleya sp., J. Protozoology 14, Suppl. No. 139 (May 1967). S.

Komárek, J., Vayra, J., In Memoriam of Marssoniella Lemm. 1900, Arch. Protistenk. 111, 12-17 (1968). S.

Kondrateva, N. V., Pro nomenklaturu sino-zelenich vodorostej u kulturi. (Nomenclature of BlueGreen Algae in Culture), Ukr. bot. Z. 24, 50-55 (1967), ukrainisch, mit englischer Zusammenfassung. $\mathrm{K}, \mathrm{S}$.

Kondrateva, N. V., "Vibuchopodibne" rujnuvannja klitin planklonnich vidiv anaben. ("Explosive" Cell Destruction of the Planktonic Anabaena Species), Ukr. bot. Z. 24, 66-73 (1967), ukrainisch, mit englischer Zusammenfassung. $\mathrm{O}$.

Kopteva, Ž. P., Azotfiksimujušcaja sposobnost nekotorych sinezelenych vodoroslej. (Nitrogen-Fixing Ability of Some Blue-Green Algae), Mikrobiol. Z. 29, 95-99 (1967), russisch mit englischer Zusammenfassung. PN.

Kordyum, V. A., Ratushnaya, M. Y., Smirnova, M. M., Weisband, S. M., On the Mineral Nutrition of Anabaena variabilis, Mikrobiol. J. 28, 57-63 (1967). K.

Kordyum, V. A., Smirnova, M. N., Fixation of Molecular Nitrogen by Some Representatives of the General Anabaena and Nostoc, Mikrobiol. J. 28, 19-23 (1967). PN.

Kokinex, V., Primary Production of Plankton in Ponds in the Vicinity of Blatná, Arch. Hydrobiol. 63, 529-532 (1967). O.

Kosenko, L. V., RAšBA, O. J., Vivčennja vmistu vuglevodiv u klitinach dejakich azotfiksujusčich sino-zelenich vodorostej. (Kohlenhydratgehalt in Zellen einiger stickstoffbindender Blaualgen), Mikrobiol. Z. 6, 487-490 (1967). PN.

KR JUČKova, N. M., Uloha zooplanktonu prĭ samočištěni znečištěných vod. (The Effect of Zooplankton in Selfpurification of Polluted Water), Vodní Hospod. (Praha) 77, 391 (1967), tschechisch. V (Synechococcus).

KRzeczkowska-Woloszyn, I., Plankton starych tarlish karpiowych w gospodarsiwie Golysz. (Das Plankton in alten Karpfenlaichieichen der Teichwirtschaft Golysz), Acta Hydrobiol. 9, 381-394 (1967), polnisch. O (inkl. Cyanophyceae).

KRzECzkowska-Woloszyn, L., Plankton nowych stawów tarliskowych w Gospodarstwie Golysz. (Das Plankton der neuerbauten Laichteiche der Teichwirtschaft Gotysz), Acta Hydrobiol. 9, 395-425 (1967), polnisch. O (inkl. Cyanophyceae).

Kumar, H. D., Singh, H. N., Prakash, G., The Effect of Proflavine on Different Strains of the Blue-Green Alga Anacystis nidulans, Plant Cell Physiol. 8, 171-179 (1967). B.

KuzMINko, M. I., Ispolzovanie aminokislol sinezelenoj vodorosli Microcystis aeruginosa. (A usnïlzung der Aminosäuren der Blaualge Microcystis aeruginosa), Tzd. "Naukova dumka», 1967. B.

LABerge, L. G., Microfossils and Precambrian Iron Formation, Geol. Soc. of Am. Bull. 78(3), 1967. V.

LANG, N. J., RAE, P. M. M., Structures in a Blue-Green Alga Resembling Prolamellar Bodies, Protoplasma 64, 67-74 (1967). Cu.

LANGE, W., Effect of Carbohydrates on the Symbiontic Growth of Planktonic Blue-Green Algae with Bacteria, Nature (London) 215, 1277-1278 (1967). P, O.

Laporte, G. S., Pourriot, R., Fixation de l'azote atmosphérique par les algues cyanophycées, Rev. Ecol. Biol. sol 4, 81-112 (1967). PN.

LEAK, L. V., Fine Structure of the Mucilaginous Sheath of Anabaena sp., J. Ultrastr. Res. 21, 61-74 (1967). Cu.

LEAK, L. V., Studies on the Preservation and Organization of DNA-Containing Regions in a BlueGreen Alga, a Cytochemical and Ultrastructural Study, J. Ultrastr. Res. 20, 190-210 (1967). B, $\mathrm{C} \mathrm{U}$,

LeAK, L. V., Burke, J. F., The Application of Freeze-Fracture Replication in Studying the Fine Structure of a Blue-Green Alga, Exp. Cell Res. 48, 300-306 (1967). Cu (Anabaena).

LeEnTVAaR, P., Observations in Guanotrophic Environments, Hydrobiologia 29, 441-489 (1967). O.

LEFORT, M., POUPHILE, M., Données cytochimiques sur l'organisation structurale du chromatoplasma de Glaucocystis nostochinearum, C. R. Acad. Sci. Paris (1967). B, Cu.

LÉONARD, J., Compère, P., Spirulina platensis (Gom.) Geill. algue bleue de grande valeur alimentaire par sa richesse en protéines, Bull. Jard. bot. nat. Belg. 37, suppl., 23 (1967). S, O. 
Lipnickaja, G. P., KRuglov, J. V., Vlijanie triozinovych gerbicidov na počvennye vodorosli. (Der Einfluss von Triozin-Herbiziden auf Bodenalgen), Sovr. sostojanie i perspektivy izučenija pođ̌v. vodoroslej v SSSR (Kirov) 20, 222-226 (1967). P.

delisle, D. G., Takahashi, D. H., Weeber, S. W., Preliminary Survey of the Algae of Lake A hquabi, Proc. Iowa Acad. Sci. 72, 62-65 (1967). O.

Luty, E. T., Hoshaw, R. W., Airborne Algae of the Tucson and Santa Catalina Mountain Aveas, J. Arizona Acad. Sci. 4, 179-182 (1967). O.

Lvov, N. P., Novye formy svobodnozivustich azotfiksatorov. (Neue Formen von freilebenden stickstoffbindenden Organismen), Biologiðeskij azot v s/ch, p. 205-220 (1967). PN.

Malisin, S., Theoretical Analysis of the Enhancement Effect in Photosynthesis: Evidence for the "Spill-Over» Model, Biophys. J. 7, 629-649 (1967). P.

MAUGini, E., Cytological Site of Glycogen in Nostoc commune Vaucher, Caryologia 20, $41-49$ (1967). $B$.

Mickelson, J. C., Davis, E. B., Tischer, R. G., The Effect of Various Nitrogen Sources Upon Heterocyst Formation in Anabaena flos-aquae A-37, J. exp. Bot. 18, 397-405 (1967). P.

Mišustin, E. N., Biologičeskij azot v s/ch SSSR. (Biologischer Stickstoff in der Landwirtschaft der $U d S S R$ ), Sovr. sostojanie i perspektivy izučenija počv. vodoroslej v SSSR (Kirov) 20, 41-47 (1967). PN.

Mršustin, E. N., Peterburgskij, A. V., Biologičeskij azot v selshom chozjajstve. (Biologischer Stickstoff in dev Landwirtschaft), Biologičeskij azot v s/ch, 5-12 (1967). PN.

Mitra, A. K., Pandey, D. C., On a New Genus of the Blue-Green Alga Chlorogloeopsis with Remarks on the Production of Heterocysts in the Alga, Phykos 5, 106-114 (1967). S.

Moore, R. B., Algae as Biological Indicators of Pesticides, J. Phycol. 3 (suppl.), p. 4 (1967). V (inkl. Nostoc).

Morar, S. N., Stimuljacija razvitija sine-zelenoj vodorosli Phormidium v polevych uslovijach. (Entwicklungsstimulation der Blaualge Phormidium in Feldbedingungen), Sovr. sostojanie i perspektivy izučenija počv. vodoroslej v SSSR (Kirov) 20, 294-297 (1967). O, P.

Morozova, R. S., Tomina, Z. V., Fedorov, V. D., Fine Structure of Parachromatophores in the Blue-Green Alga Anacystis nidulans, Mikrobiologiya 36, 471-474 (1967). Cu.

Müller, H., Eine neve qualitative Bestandesaufnahme des Phytoplanktons des Bodensee-Obersees mit besonderer Beriucksichtigung der tychoplanktischen Diatomeen, Arch. Hydrobiol., Suppl., 33, 206-236 (1967). S.

Murano, F., Fujita, Y., Comparative Studies of Photochemical Oxidation-Reduction Reactions in Lamellar Fragments of Various Algae and Spinach, Plant Cell Physiol. 8, 673-682 (1967). P (inkl. Cyanophyceae).

Murata, N., Takamiya, A., Changes in Emission Spectra of Photosynthetic Pigments in Vivo, Plant Cell Physiol. 8, 683-694 (1967). P (inkl. Cyanophyceae).

NAIR, G. U., The Myxophyceae of Kevala State India, Lab. Dev. J. Sci. Tech. 5, 160-162 (1967). O, S.

NAIR, G. U., The Nostocaceae of Kanpur-II, Hydrobiologia 30, 145-153 (1967). O, S.

Neufeld, G. J., Structural Characterization of Phycocyanin and Phycoerythrin, Diss. Abstr. [10B] $27,3720 \mathrm{~B}(1967)$. B.

NiEwolak, ST., O wystepowaniu $i$ roli bakterii fotosynietyzujacych w zbiornikach wodnych. (Uber das Auftreten und die Rolle der photosynthetischen Bakterien in Geqüssern), Wszechświat 1968, p. 148-151, polnisch. P, V.

Norris, R. E., Notes on Marine Algae of Washington and Southern British Columbia. II., Madrono 19, 111-116 (1967). O.

Norton, J. S., A Comparative Study of ENZ Nuclease Activity in Algae, Diss. Abstr. 28, [2B] $480 \mathrm{~B}(1967)$. B (Anacystis).

Norton, J., Roth, J. S., Some Aspects of Nuclease Activity in Anacystis nidulans and Other Algae, Comp. Biochem. Physiol, 23, 361-371 (1967). B.

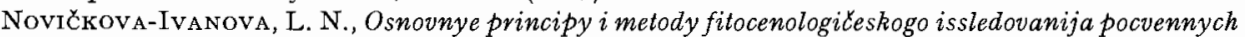
vodoroslej. (Grundprinzipien und Methoden der phytocoenologischen Untersuchungen dev Bodenalgen), Sovr. sostojanie i perspektivy izucenija pocv. vodoroslej v SSSR (Kirov) 20, 48-53 (1967). O.

Nultsch, W., Einfluss von Redox-Systemen auf die Bewegungsaktivität und das phototahtische Reaktionsverhalten von Phormidium uncinatum, Arch. Mikrobiol. 63, 295-320 (1968). P. 
Olive, J. H., Morrison, J. H., Variations in Distribution of ${ }^{\mathbf{1 4}} \mathrm{C}$ in Cell Extracts of Phytoplanhton Living Under Natural Conditions, Limnol. Oceanogr. 12, 383-391 (1967). B (Oscillatoria rubescens).

Oliveira, P. H., Lejeune, DE, Sur la biologie de la Chroococcacée Gomphosphaeria aponina Ktz. avec des notes sur l'évolution d'une population planctonique tropicale d'eau douce, $\mathrm{C}$. $\mathrm{R}$. Soc. Biol. (Paris) 161, 970-972 (1967). P, B.

Oró, J., Tornabene, T. G., Nooner, D. W., Gelpi, E., Aliphatic Hydrocarbons and Fatty Acids of Some Marine and Freshwater Microorganisms, J. Bact. 93, 1811-1818 (1967). P.

Osmanova, P., Ob ucastii sinezelenych vodoroslej $v$ obogašenii serozelenych podv azotom. (Über den Anteil der Blaualgen an dev Stickstoffanreicherung der graugrünen Böden), Izv. AN Turkm. SSR 6, 17-21 (1967). PN.

OttovA, V., $K$ otáskám biologie oxidacnich prikopú. (On Questions of Biology of Oxidation Ditches), Vodní Hospod. (Praha) 17, 257-260 (1967), tschechisch, mit englischer Zusammenfassung. O (Microcystis, Oscillatoria).

Overbeck, J., Zur Bakteriologie des Sïsswassersees - Ergebnisse und Probleme, Gas- und Wasserf. 108, 44, 1258-1260 (1967). O (inkl. Oscillatoria, Aphanizomenon).

Padan, E., Shilo, M., Kislev, N., Ioslation of Cyanophages from Fresh Water Ponds and their Interaction with Plectonema boryanum, Virology 32, 234-246 (1967). O, K.

Padmaja, T. D., Desikachary, T. V., Trends in the Taxonomy of Algae, Sympos. newer Trends in Taxonomy 34, 338-364 (1967). S (espec. Cyanophyceae).

Palmer, C. M., Biological Aspects of Water Supply and Treatment in Virginia with Particular Reference to Algae, Virginia J. Sci. 18, 6-12 (1967). O.

Pankratova, E. M., Izmenenie sostava kulturnoj sredy v processe rosta počvennych sine-zelenych vodoroslej. (Veränderungen des Kulturmediums während des Wachstums der Bodenblaualgen), Sovr. sostojanie i perspektivy izučenija počv. vodoroslej v SSSR (Kirov) 20, 202-207 (1967). K.

PANdey, D. C., A Note on the Germination of Heterocysts in Anabaena naviculoides Fritsch, Current Science $36(13), 358(1967)$. $\mathrm{P}$.

Pandey, D. C., Observations on Anabaena naviculoides Fritsch, Current Science 36, 471 (1967). P.

Papageorgiou, G., GovindjeE, Changes in Intensity and Spectral Distribution of Fluovescence: Effect of Light Treatment on Normal and DCMU-Poisoned Anacystis nidulans, Biophys. J. 7, 375-389 (1967). P.

Papageorgiou, G., Govindjee, Oxygen Evolution from Lyophilized Anacystis with Carbon Dioxide as Oxidant, Biochim. biophys. Acta 131, 173-178 (1967). B.

Parker, P. I., van BaAlen, C., Maurer, L., Fatty Acids in Eleven Species of Blue-Green Algae: Geochemical Significance, Science (New York) 155 (3763), 707-708 (1967). B.

PARriaud, H., Contribution à l'étude de la flore algologique d'une source chlorurée sodique des environs de Dax. I. Chlorophycées, Chrysophycées, Xanthophycées et Cyanophycées, Botaniste 50, 331-338 (1967). S.

Patalas, K., Landscape and Climate as Factors in the Mass Development of Algae, Fortschr. Wasserchem. Grenzgeb. No. 8, 21-31 (1968). O, B (inkl. Cyanophyceae).

Pavoni, M., 4. Symposium über Fragen der Cyanophytensystematik im Kastanienbaum, 1966, Schweiz. Z. Hydrol. 29, 161-171 (1967). S.

Pavoni, M., Blaualgenliteratur aus den Jahren 1960 1966, Schweiz. Z. Hydrol. 29, 226-250 (1967). V.

Pearce, J., Carr, N. G., An Incomplate Tricarboxylic Acid Cycle in the Blue-Green Alga Anabaena variabilis, J. Biochem. 105, p. 45 p (1967). B.

Pearce, J., CARR, N. G., The Metabolism of Acetate by the Blue-Green Algae, Anabaena variabilis and Anacystis nidulans, J. gen. Microbiol. 49, 301-313 (1967). B.

PEAT, A., Environmental Effects on the Fine Structure of Chlorogloea fritschii Mitra, Brit. phycol. Bull. 3, 411 (1967). Cu, O.

Peat, A., Whitton, B. A., Environmental Effects on the Structure of the Blue-Green Alga, Chlorogloea fritschii, Arch. Mikrobiol. 57, 155-180 (1967). Cu, O.

Pechlaner, R., Die Finstertaler Seen (Kühtai, Osterreich). I I. Das Phytoplankton, Arch. Hydrobiol. 63, 145-193 (1967). O (inkl. Cyanophyceae).

Perminova, G. N., Vlijanie sine-zelenych vodoroslej na azotnyj režim poǔvy i urožaj rastenij. (Der Einfluss von Blaualgen auf den Stickstoffhaushalt des Bodens und auf die Pflanzenproduktion), Sovr. sostojanie i perspektivy izu ̌enija počv. vodoroslej v SSSR (Kirov) 20, 241-245 (1967). O, PN. 
Perminova, G. N., Vlijanie sine-zelenych vodoroslej na nakoplenie azota v počve. (Der Einfluss der Blaualgen auf die Stichstoffspeicherung in Böden), Tr. Kirovskogo s/ch Inst. (Kirov) 19, 16-24 (1967). O, PN.

Petrova, A. N., UČet razvitija vodorosiej v risovych poljach metodom obrastanija. (Feststellung der Algenentwicklung auf Reisfeldern durch die Bewuchsmethode), Sovr. sostojanie i perspektivy izucenija pocv. vodoroslej v SSSR (Kirov) 20, 60-64 (1967). O.

Prennig, N., Cohen-BezIre, G., Some Properties of the Green Bacterium Pelodictyon Clathratiforme, Arch. Mikrobiol. 59, 226-236 (1967). S (inkl. Cyanophyceae).

Pignatti, S., de Cristini, P., Rizzi, L., The Algal Association of the Mavine Cave "Grotta delle Viole» (S. Domino, Tremiti Islands), G. Bot. Ital. 101, 117-126 (1967). O (inkl. Cyanophyceae).

PIKÁLEK, P., Attempt to Find Genetic Recombination in Anacystis nidulans, Nature (London) 275 (5101), 666-667 (1967). C, P.

Pinevič, V. V., KovaČEva, N. G., Massovoe kultivirovanie sinezelenych azotfiksurujušcich vodorosiej. (Über die Massenkultivation der stickstoffbindenden Blaualgen), Biologiceskij azot i ego rol v zemedelii, Izd. "Nauka», M: 342-354 (1967). PN.

PINevič, V. V., KovaČEva, N. G., Vlijanie uslovij vozdušnogo pitanija na rost $i$ usvoenie azota nekotorymi sine-zelenymi vodorosljami. (Einfluss der Lufternährungsbedingungen auf Wachstum und Stickstoffaufnahme einiger Blaualgen), Sovr. sostojanie i perspektivy izučenija počv. vodoroslej v SSSR (Kirov) 20, 167-182 (1967). PN.

Platonova, V. P., Dejstvie 2,4-D simozina i prometrina na poúvennye vodorosli. (Einfluss von 2,4-D Simozin und Prometrin auf die Bodenalgen), Sovr. sostojanie i perspelstivy izucenija počv. vodoroslej v SSSR (Kirov) 20, 215-221 (1967). B.

PótToRacka, J., Shlad gatuhkowy fitoplanktonu w jeziovze podgrzewanym przez elektrownie cieplnq oraz w jeziorach o normalnej temperaturze. (Specific Composition of Phytoplankton in a Lake Warmed by Waste Water from a Thermoelectric Plant and Lakes with a Normal Temperature), Acta Societatis Botanicorum Poloniae 37, 297-325 (1968), polnisch. O (inkl. Cyanophyceae).

Powls, R., Redfearn, E. R., The Tocopherols of the Blue-Green Algae, Biochem. J. 104, 240 (1967). B.

Pringsheim, E. G., Die Mixotrophie von Beggiatoa, Arch. Mikrobiol. 59, 247 (1967). P.

Pringsheim, E. G., Cyanophyceen-Probleme, Planta (Berl.) 79, 1-9 (1968). S, O, P.

Pringsheim, E. G., Oscillatoria agardhii var. suspensa nov. var., Arch. Mikrobiol. 63, 401-413 (1968). S.

Pringsheim, E. G., Cyanophyceen-Studien, Arch. Mikrobiol. 63, 331-355 (1968). S, O, P.

Proškina-Lavrenko, A. I., Makarova, I. V., Vodorosli planktona Kaspijskogo morja. (Planktonalgen des Kaspischen Meeves), Izd. "Nauka» (Leningrad), 291 pp. 1967. O.

Quillet, M., Sur le sacchavose et les glucides vacuolaives de deux espèces d'Algues bleues: Rivularia bullata (Berk.) et Nostoc commune (Vauch.), C. R. hébd. Séanc. Acad. Sci. [sér. D nat.], (Paris) 264, 1718-1720 (1967). B.

Ramamurthy, V. D., Krishnamurthy, S., The Antibacterial Properties of Marine Blue-Green Alga Trichodesmium erythraeum (Ehr.), Curr. Sci. 36, 524 (1967). P.

RaTHSACK, R., Cyanophyceen aufGiftanstrichen, Verh. int. Verein. Limnol. 16, 1575-1576 (1967). O.

Rathsack-KüNzENBACH, R., Untersuchungen über die Struktur des Centroplasmas und die Drehvichtung einiger Oscillatoriaarten, Schweiz. Z. Hydrol. 29, 185-190 (1967). C.

Ratušna, M. J., Kosenko, L. V., Kirilova, V. S., Sakoda, V. S., Pro chimičnij shlad dejakich sino-zelenich vodorostej. (Chemical Composition of Some Blue-Gveen Algae), Mikrobiolog. Z. 29, 30-33 (1967), ukrainisch mit englischer Zusammenfassung. B.

ReEse, J. A., A Study of the Fine Structure of the Blue-Green Alga Nostoc musconum, Diss. Abstr. $28,67-68$ (1967). Cu.

Reichardt, W., Overbeck, J., Steubing, L., Free Dissolved Enzymes in Lahe Waters, Nature (London) 276 (5122), 1345-1347 (1967). O (ink1. Cyanophyceae).

Reir, C. B., Fine, D. L., Two Winter Blwe-Green Algal Populations, Phycologia 6, 105-106 (1967). B, S.

ReItz, R. C., Lipids of Algae: (a) Sterol and Fatty Acids of Blue-Green Algae, (b) Fatty Acids of Synchronous Cultures of Chlorella pyrenoidosa, Diss. Abstr. 27 [10B], 3398 B-3399 B (1967). B (Anacystis, Fremyella). 
Revill, D. L., Stewart, K. W., Schlichting, H. E., Passive Dispersal of Viable Algae and Protozoa by Certain Craneflies and Midges, Ecology 48,1023-1027 (1967). O (inkl. Cyanophyceae).

Ridgway, J. E., The Biotic Relationship of Anthoceros and Phaeoceros to Certain Cyanophyta, Ann. Missouri bot. Garden 54, 95-102 (1967). O.

Rizzi, L., Pignatti, S., Froglia, C., Flora delle acque circostanti dell'isola di Pianosa (Is. Tremiti), G. Bot. Ital. 107, 237-239 (1967). O (inkl. Cyanophyceae).

Rizzi, L., Pignatti, S., DE Cristini, P., Contribuzione alla flora algologica del litorale Garganico mevidionale fra Manfredonia é Mattinata, G. Bot. Ital. 107, 131-132 (1967). O.

Rogers, T. D., Scholes, V. E., Schlichting, H. E. Jr., Freezedrying of Blue-Green Algae for Electron Microscope Studies, J. Phycol. 3, 161-165 (1967). Cu.

RubENČı, L. I., ref. L. N. Pšenin-Biologiya morskich azotfiksatorov, Kiev, 1966. (Biology of Marine Nitrogen Fixing Microorganisms), Mikrobiologiya 36, 369-372 (1967). PN.

Ržanova, G. N', Vnekletočnye azotsoderžaščie veščestva dvuch azotfiksirujuščch vidov sine-zelenych vodoroslej. (Cell-Free Nitrogen-Containing Substances of Two Nitrogen Fixing Species of BlueGreen Algae), Mikrobiologija 36, 639-645 (1967). PN.

Sacharova, N. I., Kuzmen Ko, M. I., Vlijanie aminokislot na žiznedejatelnost nekotorych sinezelenych vodoroslej $i$ soputstwujuščju mikrofloru. (Der Einfluss von Aminosäuren auf die Lebensprozesse einiger Blaualgen und der begleitenden Mikroflora), Tzd. "Naukova dumka" (1967).

SAČKova, P. O., $K$ metodike vydelenija stevilnych kultur azotfiksirujuščch sinezelenych vodoroslej. (Zur Methodik der Gerinnung von sterilen Kulturen der stickstoffbindenden Blaualgen), Materialy konferencii molodych učenych (Alma-Ata), p. 19-20 (1967). PN.

Saffermann, R. S., Morris, M. E., Observations on the Occurvence, Distribution, and Seasonal Incidence of Blue-Green Algal Viruses, Appl. Microbiol. 15, 1219-1222 (1967). O, P.

Sankaram, A., Mudholkar, N. J., Sahay, M. N., Inoculation of Blue-Green Algae on the Yield of Rice Under Field Conditions, Ind. J. Microbiol. 7, 57-62 (1967). O.

Schmitz, R., On the Composition of the Pigment-Containing Structures of the Purple Bacterium Rhodopsendomonas sphaeroides, Z. Naturforsch. 22b, 645-648 (1967). Cu.

Sснмтт, R., Über die Zusammensetzung der pigmenthaltigen Strukturen aus Prokaryonten. I. Untersuchungen an Thylakoiden von Oscillatoria chalybaea Kütz., Arch. Mikrobiol. 56, 225-237 (1967). $\mathrm{Cu}, \mathrm{B}$.

Schwabe, G. H., Microchaete tenera Thur. als Vertreter der pleistomorphen Schicht des Cyanophytenstamms, Nova Hedwigia 73, 423-448 (1967). O, S.

Schwabe, G. H., Mollenhauer, R., Öber den Einfluss der Begleitbahterien auf das Lagerbild von Nostoc sphaericum, Nova Hedwigia 73, 77-80 (1967). O, S.

Shapiro, J., Iron Available to Algae: Preliminary Report on a New Approach to its Estimation in Lake Water through Use of the "Ferrigram», Proc. IBP-Symposium, 10-16 October 1966 (Amsterdam), p. 219-228 (1967). O (inkl. Cyanophyceae).

Sheridan, R. P., Photochemical and Dark Reduction of Sulfate and Thiosulfate to Hydrogen Sulfide in Synechococcus lividus, Diss. Abstr, 27 (11B), 3799 B--3800 B (1967). B.

Shimony, C., Spencer, J., Govindjee, Spectral Characteristics of Anacystis Particles, Photosynthetica $1,113-125$ (1967). P.

Shulka, A. C., Effect of Algal Hormones on Stomatal and Epidermal Development in Rice Leaves, Hydrobiologia 30, 221-224 (1967). V.

Siedlicka-Binder, Z., Aquatic Vegetation in the Brooks of the Ojcow National Park, Ochrona Przyrody 32, 171 (1967). O (inkl. Cyanophyceae).

Siegelman, H. W., Chapman, D. J., Cole, W. J., Enzymatic Cleavage of Phycocyanobilin, Arch. Biochem. Biophys. 122, 261 (1967). B (Phormidium).

Siemińska, A., Siemińska, J., Flora and Fauna in the Region of the Experimental Farms of the Polish Academy of Sciences and of Goczalkowice Reservoir, Silesia, Acta Hydrobiologica 9 , 1-109 (1967), englisch. S (inkl. Cyanophyceae).

SicmiŃska, J., Algae from the Toporowy Staw Wyzni Lake in the Tatra Mts., Acta Hydrobiol. 9 , 169-185 (1967), englisch. S (inkl. Cyanophyceae).

Singh, H. N., Genetic Control of Sporulation in the Blue-Green Alga Anabaena doliolum Bharadwaja, Planta 75, 33-38 (1967). P.

SingH, R. N., SingH, P. K., Isolation of Cyanophages from India, Nature (London) 276, 1020-1021 (1967). V. 
Sirenko, L. A., Fiziologo biochimieni osoblivosti metabolizmu sino-zelenych vodorostej $v$ svitii novitnich danich. I. Citologicni osoblivosti. Pigmenti sistemi $i$ ich učastu fotosintezi fermenti. (Physiologisch-biochemische Besonderheiten des Blaualgenstoffwechsels im Lichte der neuen Erkenntnisse. I. Cytologische Besonderheiten. Pigmentsysteme und ihve Anteile der an der Photosynthese beteiligten Fermente), Ukr, botan. Z. 24, 3-18 (1967). P, C.

Sirenko, A. A., SAkeviC, A. I., Obrazovanie terpenov u sine-zelenych vodoroslej. (Úber die Terpenentstehung bei Blaualgen), Dokl. AN SSSR, 177, 959-960 (1967). B.

Skinder, N. W., Perspektywy wykorzystania w praktyce wynikow badan nad fizjologiq sinic. (Perspehtiven für die praktische Anwendung von Forschungsergebnissen über die Physiologie der Blaualgen), Wszechswiat 1967, 275-278, polnisch. P.

SKINDER, N. W., Sinice-jako organizmy symbiotyczne. (Die Blaualgen als symbiontische Organismen), Wszechswiat 1968, 228-229, polnisch. P.

Skinder, N. W., Problem toksyczności sinic. (Das Problem der Toxizitat der Blanalgen), Wiadomości botaniczne 12, 125-127 (1968), polnisch. PT.

SKINDER, N. W., Metody inhibowania rozwoju niektórych glonów. (Die Inhibitionsmethoden der Entwicklung einiger Algen), Gospodarka Rybna 5, 5-6 (1968), polnisch. P, V.

Skinder, N. W., STabrowska, J., Perspektywy wykorzystania algicydów w gospodarstwach rybackich. (Perspektiven fïr die Anwendung von Algiziden in Teichwivtschaften), Gospodarka Rybna 2, 20-21 (1968), polnisch. PT, V.

Skinder, N. W., Stabrowska, J., Pozahomórhowe (extracellularne) produkty glonow $i$ ich znaczenie w zbiornikach wodnych. (Extrazelluläre Produkte der Algen und ihre Bedeutung in Gewässern), Gospodarka Rybna 11, 20-21 (1968), polnisch. P.

Sмiтн, R. V., Electron Microscope Studies of the Gas-Vacuoles of Myzophyceae (Abstract), Brit. phycol. Bull. 3, 412 (1967). Cu.

Smith, A. J., London, J., Stanier, R. Y., Biochemical Basis of Obligate A utotrophy in Blue-Green Algae and Thiobacilli, J. Bact. 94, 972-983 (1967). B.

Smith, R. V., PEAT, A., Comparative Structure of the Gas-Vacuoles of Blue-Green Algae, Arch. Mikrobiol. 57, 111-122 (1967). Cu.

Smith, R. V., PeAt, A., Growth and Gas-Vacuole Development in Vegetative Cells of Anabaena flos-aquae, Arch. Mikrobiol. 58, 117-126 (1967). Cu.

Sournia, A., La cyanophycée Oscillatoria (Trichodesmium) dans le plancton Marni, Nova Hedwigia 15, 1-12 (1968). B, O.

Spataru, P., Gruia, L., Die biologische Stellung des Bitterlings Rhodeus sericeus amarus im Flachseekomplex Crapina-Jijila. (Überschwemmungsgebiet der Donau, Rumänien), Arch. Hydrobiol., suppl. 30, 420-432 (1967). V (inkl. Cyanophyceae).

Spodniewska, I., Dynamics of the Abundance and Biomass of Phytoplankton in Lakes Mikolajskie and Taltowisko, Ekologia polska [A] 15, 139-153 (1967). O (ink1. Cyanophyceae).

Spodniewska, I., On the Methodical Studies of the Representativeness of Phytoplankton Samples, Ekologia polska [A] 15, 487-494 (1967). V (inkl. Cyanophyceae).

Srecenskaja, N. I., Sine-zjalenyja vodorosci Belaruskaga Palessja. (Blaualgen des Gebietes von Belarusko Palessje), Vesci Akad. Belaruskoj SSR, ser. bijag. 3, 70-82 (1967). O.

Staehelin, L. A., Plasmalemma and Cell Wall During Life Cycle of Cyanidium caldarium, N. Z. Med. J. 66, 389 (1967). C.

StangenberG, M., Toxic Effects of Microcystis aeruginosa Kg. Extracts on Daphnia longispina O. F. Müller and Eucypris virens Juvine, Hydrobiologia 32, 1/2, 81-87 (1968). P, B.

Starmach, K., Zur Taxonomie der Chroococcales, Schweiz. Z. Hydrol. 29, 172-175 (1967). S.

Steentoft, M., A Revision of the Marine Algae of Sao Tomé and Principe, J. Linnean Soc. Bot., Lond. 60, 99-146 (1967). S, B.

Steubing, L., Soil-Ecological Investigations in the Rhizosphere, Proc. Colloquium on Dynamics of Soil Communities, 5-10 September 1967 (Braunschweig), p. $72-88$ (1967). O.

Stewart, W. D. P., Nitrogen-Fixing Plants, Science, N. Y. 158, 3807, 1426-1432 (1967). PN.

StINA, E. A., Itogi $i$ zadaci eksperimentalnych issledovanij v počvennoj algologii. (Die Ergebnisse und Aufgaben der experimentellen Untersuchungen dev Bodenalgologie), Sovr. sostojanie i perspektivy izučenija počv. vodoroslej v SSSR (Kirov) 20, 3-22 (1967). O, PN.

Stina, E.. A., Balezina, L. S., Pankratova, E. M., Perminova, G. N., Tretjakova, A. N., JUNG, L. A., Rasprostranenie azotfiksirujušich vodoroslej v neorašaemych potvach SSSR. (Die 
Verbreitung von stickstoffbindenden Algen in unbewdsserten Böden der UdSSR), Biologičeskij azot 1 ego rol v zemedelii, Izd. "Nauka", M: 325-341 (1967). PN.

Stockner, J. G., Observations of Thermophilic Algal Communities in Mount Rainier and Yellowstone National Parks, Limnol. Oceanogr. 12, 13-17 (1967). B, S.

Symoens, J. J., Malaisse, F., Sur une formation de tuf calcaire observée sur le versant est du plateau des Kundelungu, Bull. Séanc. Acad. roy. Sci. (Bruxel) 6, 1148-1152 (1967). O (Phormidium).

Szalay, L., Török, M., Govindjee, Effect of Secondary Fluorescence of the Emission Spectrum and Quantum Yield of Fluovescence in Chlorophyll a Solutions and Algal Suspensions, Acta biochim. biophys. Acad. Sci. Hung. 2, 425-432 (1967). P (Anacystis),

TAlling, J. F., Rzóska, J., The Development of Plankton in Relation to Hydrological Regime in the Blue Nile, J. Ecol. 55, 637-662 (1967). O (inkl. Cyanophyceae).

Talpasayi, E. R. S., Localisation of Ascorbic Acid in Heterocysts of Blue-Green Algae, Curr. Sci. 36, 190-191 (1967). B.

TAmas, G., Horizontale Plankton-Untersuchungen im Balaton V. Uber das Phytoplankton des Sees auf Grund der im Jahre 1965 geschöpften und Netzfilter. Proben, Ann. Inst. biol. (Tihany) Hung. Acad. Sci. 34, 191-231 (1967). B, S.

TAYLOR, M. M. Jr., A Comparative Study of the Ribosomes and Ribosomal RNA from Bacteria and Fungi, Diss. Abstr. 27 (12B), 4490B (1967). B (inkl. Cyanophyceae).

Thomasson, K., Phytoplankton from Some Lakes on MT Wilhelm, East New Guinea, Blumea 15, 285-296 (1967). O.

Togasaki, R., GIBBS, M., Enhanced Dark $\mathrm{CO}_{2}$ Fixation by Preilluminated Chlorella pyrenoidosa and Anacystis nidulans, Plant Physiol. 42, 991 (1967). P.

Tomina, Z. V., Fedorov, V. D., Ultrastructure of Chlorobium thiosulphatophilum, Mikrobiologiya $36,663-666$ (1967). Cu.

Toom, Y. V., Pro saprobnist planktonnych ta bentosnych vodorostej. (Saprobity of the Plankton and Benthos Algae), Ukr. Bot. Z. 24, 29-32 (1967). O.

TRETJAkova, A. N., Sravnitelnoe izučenie stammov azotfiksirujušcich sine-zelenych vodoroslej, vydelennych iz raznych potv SSSR. (Vergleichende Untersuchungen der aus verschiedenen Böden der UdSSR isolierten stickstoffbindenden Blaualgenstamme), Ref. Kand. Dissert., Leningrad. 1967. PN.

TRETJAkova, A. N., Vlijanie stammov azotfiksirujuščch sine-zelenych vodoroslej na nakoplenie azota $i$ rost rastenij. (Einfluss der stichstoffbindenden Algenstämme auf die Stickstoffspeicherung und auf das Pflanzenwachstum), Sovr. sostojanie i perspektivy izučenija počv. vodoroslej $\mathrm{v}$ SSSR (Kirov) 20, (40), 246-254 (1967). PN.

Troxier, R. F., Lester, R., Biosynthesis of Phycocyanobilin, Biochemistry 6, 3840-3846 (1967). B.

Uherkovich, G., Beitrage zur Kenntnis des Fyrisan-Phytoplanktons, Svensk bot. Tidskr. 67, 193-208 (1967). O (inkl. Cyanophyceae).

Uherkovich, G., Neue und seltenere Algen aus der Theiss (Tisza) und zwei Altwässern der Theiss, Tiscia (Szeged) 3, 3-11 (1967). O (inkl. Cyanophyceae).

Uherkovich, G., U̇ber das Sommerplankton des Altwassers von Mártély, Tiscia (Szeged) 3, 13-20 (1967). O (inkl. Cyanophyceae).

UHLMANN, D., Beitrag zur Limnologie saprotropher Flachgewässer, Arch. Hydrobiol. (Stuttg.) 63, 1-85 (1967). B, S.

Ven Kataraman, G, S., Neelakantan, S., Effect of the Cellular Constituents of the Nitrogen-Fixing Blue-Green Alga Cylindrospermum muscicola, on the Root Growth of Rice Plants, J. gen. appl. Microbiol, 13, 53-61 (1967). PN.

VoGler, G., Intoxikationen von Mensch und Tier durch Phytoplanktontoxine aus Oberfldchengewässern, Arch. Hyg. Bakt. 151, 1-22 (1967). Pт.

VoLK, S. L. S., Mineral Requirements for the Growth of Anabaena spiroides in Vitro, Diss. Abstr. 27 (11B), 3801B (1967). P.

Vostrov, I. S., Osobennosti dejatelnosti požvennoj mikroflory posle zatoplenija počzy na risoyych poljach. (Besonderheiten der Tätigkeit der Bodenmikvoflora nach der Bodenüberschwemmung der Reisfelder), Sovr. sostojanie i perspektivy izučenija počv. vodoroslej v SSSR (Kirov) 20, 287-294 (1967), O, P.

Walsby, A. E., Mucilage Secretion and the Movements of Blue-Green Algae, Protoplasma (Wien) 65, $223-238$ (1968). B. 
Walsby, A. E., Eichelberger, H. H., The Fine Structure of Gas-Vacuoles Released froellsm $C$ of the Blue-Green Alga, Anabaena flos-aquae, Arch. Mikrobiol. 60, 76-83 (1967). Cu.

Watanabe, A., Yamamoro, Y., Heterotrophic Nitrogen Fixation by the Blue-Green Alga Anabaenopsis circularis, Nature (London) 214 (5089), 738 (1967). PN.

WebBer, E. E., Blue Green Algae from a Massachusetts Salt Marsh, Bull. Torrey Bot. Club 94 , 99-106 (1967). B, S.

Weber, H. L., Böck, A., Comparative Studies on the Regulation of DAHP Synthetase Activity in Blue-Green and Green Algae, Arch. Mikrobiol. 61, 159-168 (1968). P.

Whitron, B. A., Studies on the Toxicity of Polymyxin B to Blue-Green Algae, Canad. J. Microbiol. 13, 987-993 (1967). P.

Whitron, B. A., Some Comments on the Taxonomy of Blue-Green Algae, (Abstract), Brit. phycol. Bull. 3, 412 (1967). S.

Whitton, B. A., Phosphate Accumulation by Colonies of Nostoc, Plant Cell Physiol. 8, 293-296 (1967). P.

Whitton, B. A., Blue-Green Algae from Sierra Leone, Nova Hedwigia 15, 203-210 (1968). B, S.

Whitron, B. A., Effect of Light on Toxicity of Various Substances to Anacystis nidulans, Plant Cell Physiol. 9, 23-26 (1968). PT.

Whrton, B. A., MacArthur, K., The Action of Two Toxic Quinones on Anacystis nidulans, Arch. Mikrobiol. 57, 147-154 (1967). P.

Whitton, B. A., Peat, A., Heterocyst Structure in Chlorogloea fritschii, Arch. Mikrobiol. 58, 324-338 (1967). Cu.

Wolk, C. P., Physiological Basis of the Paltern Vegetative Growth of a Blue-Green Alga, Proc. nat. Acad. Sci. U.S.A. 57, 1246-1251 (1967). P (Anabaena).

Wolk, P., Daily, W. A., Lang, N. J., Lazaroff, N., The Heterocyst is it Still an Enigma? J. Phycol. 3 (suppl.), 4-5 (1967). V.

WU, J. H., Effect of Light and PCN on UV Inactivation of Virus Infective Centres in a Blue-Green Alga, 7 th Int. Congr. Biochem. (1967). B.

Wu, J. H., Shugarman, P. M., Effect of Virus Infection on Rate of Photosynthesis and Respiration of a Blue-Green Alga, Plectonema boryanum, Virology 32, 166 (1967). P.

Zarrouk, C., Rebeller, M., Clément, G., Biological Regeneration of Aiv, Fr. Pat. No. 7, 496-066 (1967). P (Spirulina).

Separatdruck aus der Schweiz. Zeitschrift für Hydrologie 31, Fasc. 1 (1969) Herausgegeben mit Unterstiitzung der Stiftung der Wirtschaft zur Förderung des Gewässerschutzes in der Schweiz 